\title{
Spectrum
}

\section{Human Immunology of Tuberculosis}

\section{THOMAS J. SCRIBA, ${ }^{1}$ ANNA K. COUSSENS, ${ }^{2}$ and HELEN A. FLETCHER ${ }^{3}$}

${ }^{1}$ South African Tuberculosis Vaccine Initiative, Division of Immunology, Department of Pathology and Institute of Infectious Disease and Molecular Medicine, University of Cape Town, South Africa; ${ }^{2}$ Clinical Infectious Diseases Research Initiative, Division of Medical Microbiology, Department of Pathology and Institute of Infectious Disease and Molecular Medicine, University of Cape Town, South Africa; ${ }^{3}$ Immunology and Infection Department, London School of Hygiene and Tropical Medicine, London, United Kingdom

\begin{abstract}
Immunology is a central theme when it comes to tuberculosis (TB). The outcome of human infection with Mycobacterium tuberculosis is dependent on the ability of the immune response to clear or contain the infection. In cases where this fails, the bacterium replicates, disseminates within the host, and elicits a pathologic inflammatory response, and disease ensues. Clinical presentation of TB disease is remarkably heterogeneous, and the disease phenotype is largely dependent on host immune status. Onward transmission of M. tuberculosis to new susceptible hosts is thought to depend on an excessive inflammatory response causing a breakdown of the lung matrix and formation of lung cavities. But this varies in cases of underlying immunological dysfunction: for example, HIV-1 infection is associated with less cavitation, while diabetes mellitus comorbidity is associated with increased cavitation and risk of transmission. In compliance with the central theme of immunology in tuberculosis, we rely on detection of an adaptive immune response, in the form of interferon-gamma release assays or tuberculin skin tests, to diagnose infection with $M$. tuberculosis. Here we review the immunology of TB in the human host, focusing on cellular and humoral adaptive immunity as well as key features of innate immune responses and the underlying immunological dysfunction which associates with human TB risk factors. Our review is restricted to human immunology, and we highlight distinctions from the immunological dogma originating from animal models of TB, which pervade the field.
\end{abstract}

Immunity to Mycobacterium tuberculosis is an interplay between the innate and adaptive immune response, both cellular and humoral. This interplay is not static but changes over time as we grow, age, and respond to our environment. Animal models enable examination of individual components of the immune response at distinct time points during the course of infection. This has enabled identification and understanding of key immune mechanisms for M. tuberculosis control. However, rational development of interventions, such as more effective vaccines and other host-directed therapies, has to take into consideration the enormous heterogeneity of the interactions between $M$. tuberculosis with human innate and adaptive immune responses, which are profoundly influenced by genetic variation, environment, and comorbidities.

Recent technological advances now being applied to the field of tuberculosis (TB) have pushed the boundaries of our understanding of the host-pathogen interactions. These include the use of highly sensitive imaging such as positron emission tomography/computed tomography (PET/CT; ${ }^{18}$ fluorodeoxyglucose positron emission and computerized axial tomographic scanning) to identify subclinical TB lesions in asymptomatic individuals to study early stages of human infection; the

\footnotetext{
Received: 9 March 2016, Accepted: 19 March 2016,

Published: 1 February 2017.

Editors: William R. Jacobs Jr., Howard Hughes Medical Institute, Albert Einstein School of Medicine, Bronx, NY 10461; Helen McShane, University of Oxford, Oxford OX3 7DQ, United Kingdom; Valerie Mizrahi, University of Cape Town, Rondebosch 7701, South Africa; Ian M. Orme, Colorado State University, Fort Collins, CO 80523

Citation: Scriba TJ, Coussens AK, Fletcher HA. 2017. Human immunology of tuberculosis. Microbiol Spectrum 5(1):TBTB2-00162016. doi:10.1128/microbiolspec.TBTB2-0016-2016.

Correspondence: Helen A. Fletcher, helen.fletcheralshtm.ac.uk (c) 2017 American Society for Microbiology. All rights reserved.
} 
explosion of high-throughput "omics" technologies for unbiased transcriptomic, genomic, proteomic, and metabolomic investigation of blood and tissues isolated from the site of disease; and the ability to isolate human M. tuberculosis-specific $T$ cell populations by the use of M. tuberculosis peptide-specific tetramers and flow cytometry. Moreover, rigorous design of clinical studies, improved and standardized clinical definitions, and extensive collection of clinical data and appropriate specimens for immunological studies have significantly advanced our understanding of human immunology. Together, these advances have led to a revolution in how we understand the different stages of M. tuberculosis infection and the interplay of innate and adaptive immunity in humans (Fig. 1).

\section{ACQUISITION OF M. TUBERCULOSIS INFECTION}

The host-pathogen interaction between M. tuberculosis and humans has been honed by thousands of years of coevolution (1). The estimation that a third of the global population is sensitized to M. tuberculosis (2) bears testament to the supreme success with which the bacterium infects, survives, and spreads within its human host. Billions of humans have experienced acquisition of $M$. tuberculosis infection. Despite this, our knowledge of the immunological events that occur during exposure and acute infection in humans is very limited. This is primarily due to the lack of diagnostic tests that directly identify M. tuberculosis in those with infection and to our limited ability to study early disease processes at the site of disease, such that the majority of human studies investigate immune responses ex vivo in peripheral blood or after in vitro infection of primary cells or cell lines.

\section{Primary Response to $M$. tuberculosis Infection}

Meticulous clinical observation of TB contacts, combined with serial tuberculin skin testing (TST) to detect the onset of hypersensitivty to M. tuberculosis antigens, allowed Arvid Wallgren to document the symptomology of incident M. tuberculosis infection in 1948 (3). He reported that most people who converted from a negative to a positive TST presented with erythema nodosum and/or fever, while many also had elevated erythrocyte sedimentation rates (3). This suggests that acute infection is associated with a systemic innate inflammatory response that precedes the induction of a detectable adaptive immune response. Erythema nodosum is still a symptomatic trigger that may lead to investigation and diagnosis of human infection with M. tuberculosis (ㅁ-므) or Mycobacterium bovis (ㄱ).

The inflammatory processes that underlie erythema nodosum, febrile illness, and erythrocyte sedimentation are thought to be causally linked to the delayed hypersensitivity reaction that underlies priming of the M. tuberculosis-specific $\mathrm{T}$ cell response. However, at least in people without prior sensitization to mycobacteria, it is likely that innate immune responses to the infecting pathogen precede these $\mathrm{T}$ cell-driven reactions. It is thought that the first event that occurs upon inhalation of M. tuberculosis-containing microdroplets is that the bacilli are taken up by alveolar macrophages (AMs). A number of important barriers and antimicrobial hurdles must be negotiated by aerosolized $M$. $t u$ berculosis particles to reach the alveoli, most of which are poorly understood in humans and are often neglected. However, it is likely that the pathogen is particularly susceptible to mechanical and immunological attack during its journey through the upper airways. A better understanding of these events, and of the cellular and humoral components that frequent the mucosal surfaces, could lead to interventions that prevent infection at the port of entry. In fact, a sizable proportion of people who are heavily exposed to M. tuberculosis do not develop any evidence for immune sensitization $(\underline{8}, \underline{9})$, suggesting that prevention of infection is possible (10).

\section{Alveolar macrophages}

AMs are regarded as the sentinels of $M$. tuberculosis infection. Their role in initial M. tuberculosis phagocytosis is unquestionable, according to animal models of infection. Defining their role in the human response to M. tuberculosis infection has been more problematic, and our knowledge can only be inferred from studies of cells collected by invasive bronchoalveolar lavage (BAL), investigation of tissue sections from autopsies, or lung resections (generally only indicated due to severe disease pathology). As a consequence, our picture of macrophage responses to in vitro $M$. tuberculosis infection is confounded by their removal from their tissue matrix and surrounding immunological milieu, including activated cytokines and other interacting cell populations. Although reductionist, the latter has provided enormous insight into differences between human AMs and peripheral monocytes.

A number of studies of BAL-isolated AMs from healthy donors have compared responses to in vitro infection with virulent $(\mathrm{H} 37 \mathrm{Rv})$ or avirulent $(\mathrm{H} 37 \mathrm{Ra})$ laboratory strains of $M$. tuberculosis (11-14). In comparison to mouse studies indicating that tumor necrosis factor 
Human Immunology of Tuberculosis

A

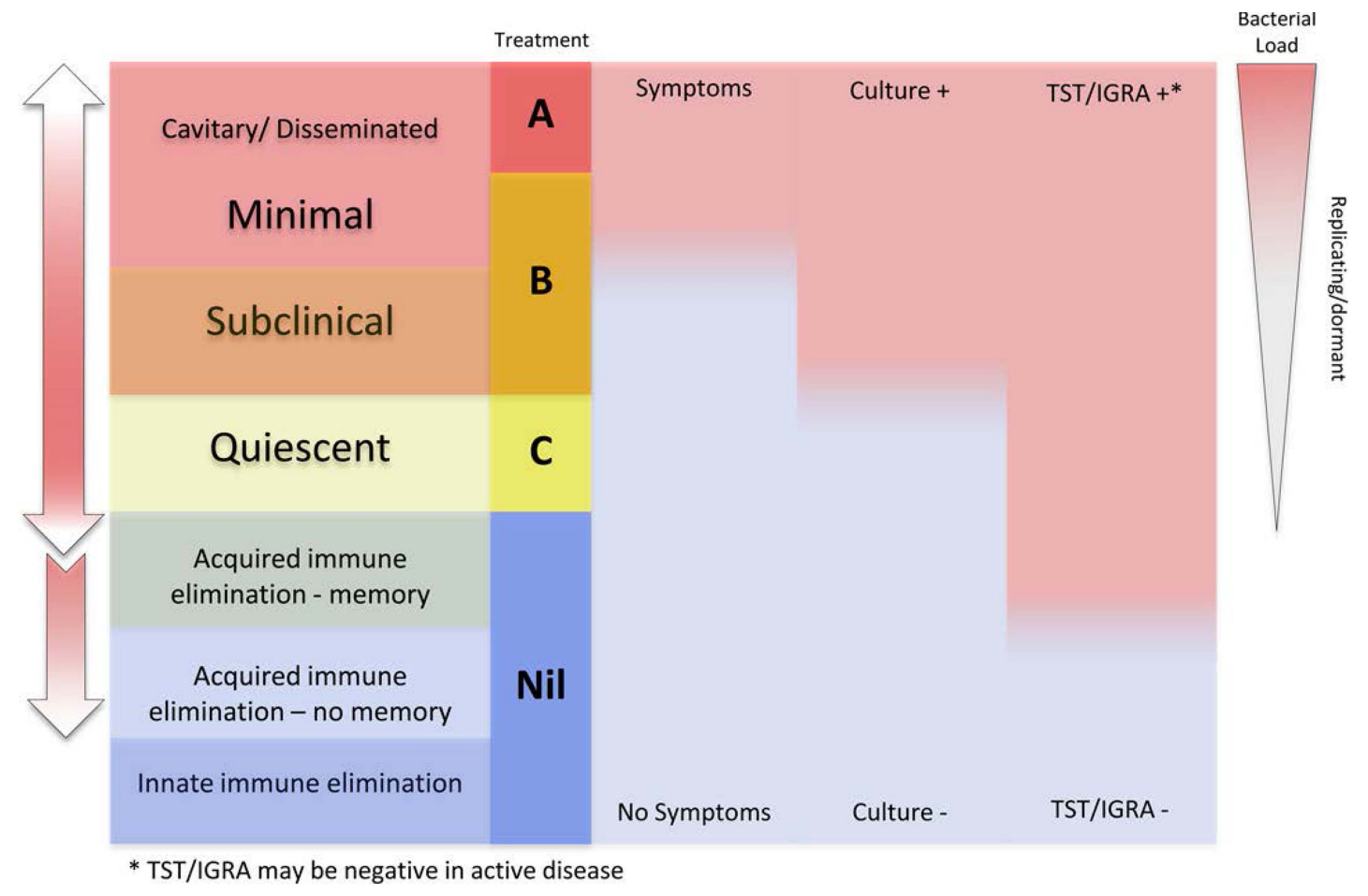

B

* TST/IGRA may be negative in active disease



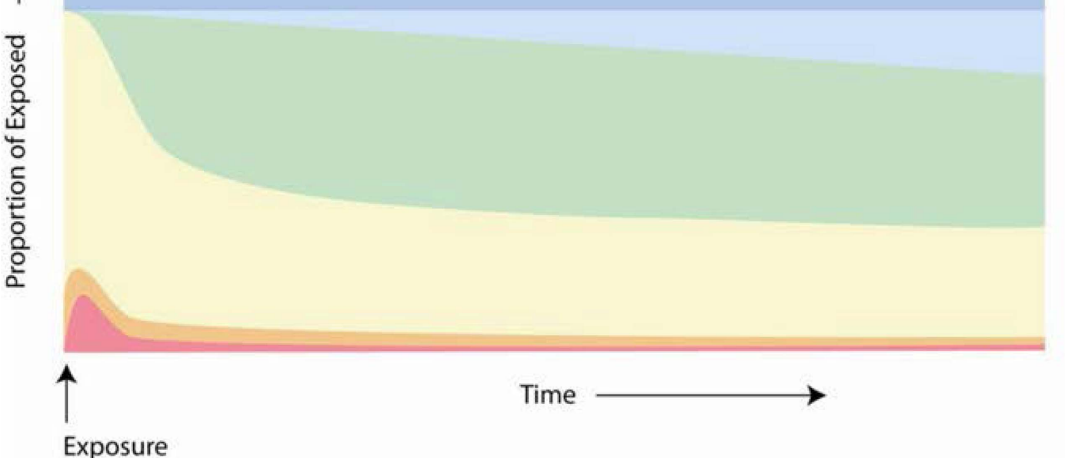

\begin{tabular}{|l|}
\hline Eliminated by innate immune response \\
$\begin{array}{l}\text { Eliminated by acquired immune response } \\
\text { no memory } \\
\text { Eliminated by acquired immune response } \\
\text { memory } \\
\text { Quiescent }\end{array}$ \\
Subclinical \\
Active
\end{tabular}

FIGURE 1 (A) Hypothesized stages of response to M. tuberculosis infection, beginning with elimination mediated by innate immune cells without induction of a long-lasting memory response; further stages of elimination may be mediated via acquired immune mechanisms. If antigen-specific effector memory persists, this can be measured via IFN- $\gamma$ release assays (IGRA) or tuberculin skin test (TST) and may provide protection from infection for a variable period of time. If the acquired immunity does not eliminate the bacteria, then infection will persist over a range of bacterial states. Increasing bacterial load is hypothesized to correlate with progression to active TB. (B) For all exposed individuals, the risk of developing TB is highest immediately following exposure and changes over time. The longitudinal risk of developing TB, predicted in the exposed individual, is presented (adapted from references $\underline{204}$ and 205). 
(TNF) provides a protective response against $M$. tuberculosis infection and that it is vital for granuloma formation, these studies showed that virulent $M$. tuberculosis induces higher levels of TNF secretion from AMs than avirulent $M$. tuberculosis, that TNF levels correlated with increased $M$. tuberculosis growth, that TNF induces apoptotic cell death in culture, that cytoxicity can be inhibited by anti-TNF treatment, and that exogenous application of TNF increases both the intracellular bacterial load and the number of infected AMs $(13,14)$. It is further hypothesized that increased apoptosis may spread the infection to neighboring AMs via efferocytosis, and extensive apoptosis has been demonstrated within caseating granulomas of lung tissue samples from TB patients (12).

Phagocytosis by AMs is mediated primarily by complement receptor 4 (CR4), whereas blood monocytes utilize CR1, CR3, and CR4. As such, uptake of M. tuberculosis can be enhanced by increasing concentrations of serum and decreased by heat inactivation of serum (15). AMs are also more efficient than monocytes at limiting intracellular growth of M. tuberculosis, and they produce high levels of TNF (15). Interestingly, phagocytosis alone is not responsible for TNF production, as uninfected AMs within the same culture also produce TNF. However, this does not occur if uninfected AMs are separated from infected AMs via a $0.4-\mu \mathrm{m}$ transwell, indicating that cell-cell interaction or a soluble factor larger than $0.4 \mu \mathrm{m}$ is required for TNF production in uninfected AMs (13).

AMs are highly heterogeneous in M. tuberculosis phagocytic potential, despite homogeneity in phagocytosis of latex beads, such that up to only $20 \%$ of AMs in culture become infected with M. tuberculosis, even with excessive infection (multiplicity of infection of 10:1 for $18 \mathrm{~h}$ ) (13). This may be mediated by variable surface expression levels of CR, while differential cytokine response can be linked to expression of pattern recognition receptor (PRR) expression. Nucleotide-binding oligomerization domain-containing protein 2 (NOD2), Tolllike receptor 2 (TLR2), and TLR4 expression on AMs is highly correlated and variable between each AM (16). The expression of PPR also changes on AMs from TB patients following treatment, indicating that the phenotype of AM changes during infection (16). The differential expression of these PPRs may be important for primary restriction of $M$. tuberculosis replication because NOD2 activation in AMs by muramyldipeptide (MDP) induces expression of interleukin-1 $\beta$ (IL-1 $\beta$ ), IL-6, and TNF; the antimicrobial peptide cathelicidin (LL-37); and the autophagy enzyme IRGM, and it restricts intracellular growth of M. tuberculosis (17).
Interestingly, LL-37 is not detected in AMs in tuberculous granulomas, suggesting that LL-37 participates only during early infection or that defects in LL-37 production can lead to $M$. tuberculosis growth and progression to disease (18).

When comparing BAL from TB patients versus healthy controls, TB AMs express higher concentrations of IL$1 \beta$, IL-6, and TNF, and this correlates with higher protein levels in BAL fluid and with IL-6 and TNF in serum (19). AMs from TB patients also show higher levels of chemokines CXCL10 (IP-10), CXCL8 (IL-8), and nuclear factor-kappa B (NF- $\mathrm{B}$ ) repressing factor (NRF), and these levels correlate with higher bacillary loads in the AMs. Interestingly, peripheral blood mononuclear cells (PBMCs) from patients with high bacillary load also have high expression of CXCL10 and CXCL8, while NRF levels are higher in AMs than in PBMCs (20).

The hyperreactivity of AMs in TB patients may be either due to an innate defect leading to susceptibility to $\mathrm{TB}$ or because $M$. tuberculosis infection changes the phenotype of AMs. The observation that the AM phenotype changes during therapy (16) supports the finding that the infection is modifying AM function. Recent evidence of a shift in the metabolic state of AMs following infection also supports this hypothesis. Macrophages can be classified as classical (M1) or alternatively activated (M2), with pro- and anti-inflammatory properties, respectively. M1s derive ATP via aerobic glycolysis and M2s via oxidative phosphorylation. M. tuberculosis infection of healthy donor AMs induces a shift from oxidative phosphorylation to aerobic glycolysis, leading to increased IL-1 $\beta$ and prostaglandin synthase PTGS2 and decreased IL-10, while blocking this shift to aerobic glycolysis leads to increased intracellular M. tuberculosis survival (21), suggesting that AM polarization to M1 activates antimicrobial activity.

\section{Neutrophils}

Peripheral neutrophilia is a hallmark of TB disease in humans and a predictor of poor outcome and morbidity $(22,23)$. The lack of neutrophil involvement in murine TB and the difficulties associated with studying neutrophils in vitro have led to limited investigation of their role in human TB. A resurgence of interest in neutrophils occurred after the first whole-blood microarray study of TB patients compared with healthy controls, which showed profound neutrophil involvement in the gene expression signature that differentiated between TB patients and controls (24). While it seems clear that neutrophils promote pathology during disease development, an understanding of their role in initial infection is more 
difficult to acquire. Recent TB contacts show increased peripheral blood neutrophil counts compared to healthy controls, and risk of $M$. tuberculosis infection has been shown to be inversely associated with neutrophil count (25). Neutrophil depletion from whole blood also decreases M. tuberculosis killing, which is primarily mediated through phagocytosis and the respiratory burst. In addition, neutrophils can kill through the release of antimicrobial peptides including human neutrophil peptides (HNPs) 1-3, LL-37, and lipocalin 2 (25). Neutrophils can also capture mycobacteria in neutrophil extracellular traps (NETs) composed of DNA coated with antimicrobial peptides (26). Interestingly, individuals of African ancestry have lower circulating neutrophil numbers and lower serum levels of HNP1-3 and lipocalin 2 compared to Caucasian individuals $(25,27)$. CXCL8, one of the chemokines most highly expressed by $M$. tuberculosis-infected AMs, with neutrophil recruiting activity, has recently been shown to bind M. tuberculosis directly and enhance phagocytosis and killing by neutrophils (28). These data suggest that neutrophils may have an early protective effect against M. tuberculosis infection.

\section{Innate T cells}

Interest in lung-resident and germline-encoded lymphocyte populations has recently been growing, with the rationale that these cells may act rapidly upon $M$. $t u$ berculosis infection. These cells naturally reside at mucosal sites in the airways and are thus ideally located to respond to invading pathogens (reviewed in reference 29). This is an important advantage over conventional $T$ cell responses that require priming in primary lymphoid tissue and subsequent differentiation into effector cells before trafficking to the site of infection. Tissue-resident $\mathrm{T}$ cells, such as mucosal-associated invariant $\mathrm{T}$ (MAIT) cells, also possess immediate effector functions, including cytokine expression and cytotoxicity, which further enable immediate antimicrobial activity. It is currently not known whether airway-resident lymphocytes play a key role in resistance to infection with $M$. tuberculosis in humans.

Most individuals who are exposed to M. tuberculosis do appear to acquire an established infection and develop readily detectable CD4 $\mathrm{T}$ cell responses to protein components of M. tuberculosis. This immune response, which typically persists for years and even decades, forms the basis for the diagnosis of human infection with M. tuberculosis, using TST or interferon gamma (IFN- $\gamma$ ) release assays (IGRAs). The utility of these diagnostic methods has been extensively reviewed (무).

\section{The Granuloma}

The structure of the granuloma is formed primarily through the coalescence of recruited macrophages around M. tuberculosis-infected macrophages, of which some differentiate into epithelioid cells and some can fuse to become multinucleated giant cells. In the typical granuloma structure these macrophages are interspersed with recruited neutrophils and are surrounded by a lymphocyte cuff, including $\mathrm{T}$ cells and $\mathrm{B}$ cells. A recent review of the historical literature has shown that granulomata are highly diverse, displaying a wide spectrum of structures and sizes and cell composition, and that this diversity can be observed even within a single host (Fig. 2; reviewed in references 31 and 32). It is thought that the granuloma functions to contain the spread of M. tuberculosis, although it can also act as a physical barrier, preventing the penetration of $\mathrm{TB}$ drugs and protecting the organism from the adaptive immune response. The phenotype of macrophages within the granuloma can affect the likelihood that the granuloma will contain M. tuberculosis, break down and transmit M. tuberculosis, and initiate an inflammatory response (33).

\section{Adaptive Responses and the Spectrum of $M$. tuberculosis Infection \\ $B$ cells}

The dominance of $\mathrm{T}$ cell responses and the concealment of M. tuberculosis within the infected macrophage suggest that antibodies would play a minor role in possible prevention of infection with M. tuberculosis during exposure. However, it has recently been recognized that $\mathrm{B}$ cells and antibodies have a variety of mechanisms for the modulation of the immune response to intracellular bacteria that are likely to be important in the control of M. tuberculosis (reviewed in references 34-37) (Fig. 3). $\mathrm{B}$ cells are a major cellular component of the lung granuloma, where they can process and present antigen to $\mathrm{T}$ cells, secrete antibodies, and modulate inflammation through the production of IL-10 (reviewed in reference 37). Although likely to be important, few clinical studies have examined the B cell response in M. tuberculosis infection. Plasmablasts and memory B cells are elevated in M. tuberculosis-infected compared to uninfected controls (38), and in vitro human B cells have been shown to ingest mycobacteria, produce IgM, and upregulate the expression of the costimulatory molecules CD80 and CD86 and the chemokine CXCL10 (39, 40). Further studies of the role of B cells in M. tuberculosis infection are required. 
Scriba et al.
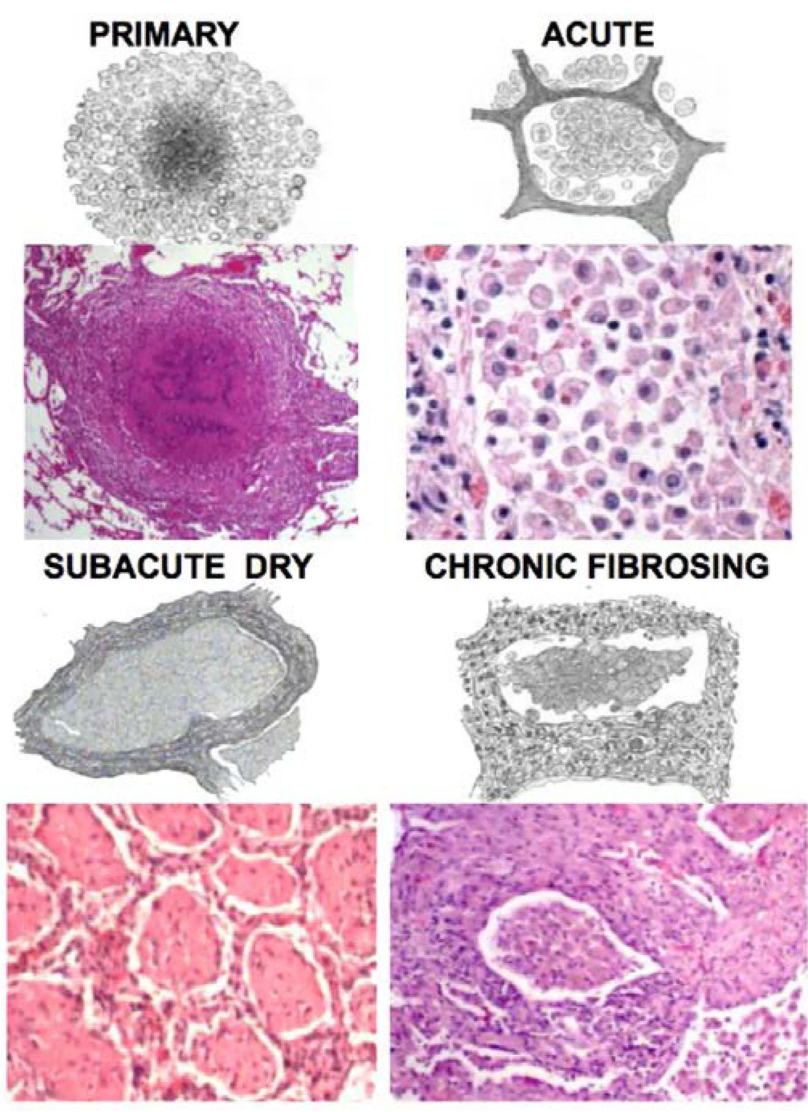

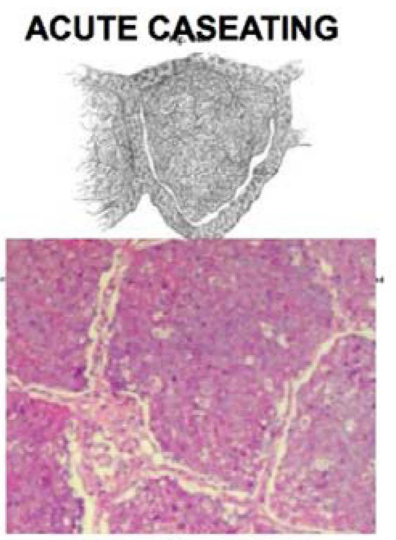

POST PRIMARY GRANULOMA
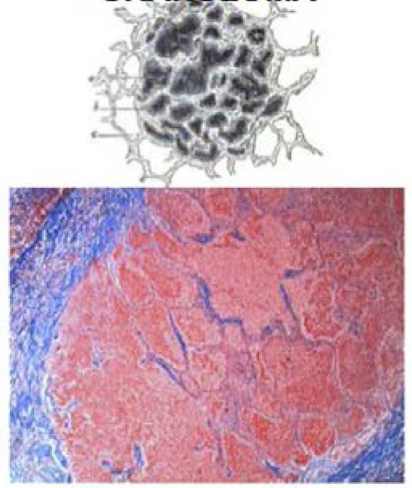

FIGURE 2 The spectrum of pulmonary TB lesions that can be found in the same host and that represent different stages of disease. Primary TB is characterized by the hallmark circular granuloma with caseating necrosis which forms within the center, surrounded by a lymphocytic cuff. Conversely, post-primary TB is typically represented by a diverse range of pathologies. Acute post-primary lesions are composed of paucibacillary lobular pneumonia; these may either resolve (subacute dry), fibrose (chronic fibrosing) or necrose (acute caseating). Caseating granulomas in post-primary TB are distinct from the granulomas of primary TB in that they form around and in response to caseous necrosis of pneumonic lesions (post-primary granuloma) rather than necrosis occurring in the center of preformed lesions as occurs in primary TB. Cavities are formed from the dissolution of these caseating pneumonic lesions. Six stages are represented by a 19th century drawing and a 21st century photomicrograph of sections stained with hematoxylin and eosin or trichrome, imaged at 40 to $400 \times$. (Reproduced from references $\underline{31}, \underline{220}$, and 221).

\section{T cells}

A lot of emphasis has been placed on the M. tuberculosis antigens targeted by $\mathrm{T}$ cell responses. Early literature has focused on $\mathrm{T}$ cell responses that recognize a relatively small set of immunodominant antigens, including early secretory antigenic target-6 (ESAT-6), $10-\mathrm{kDa}$ culture filtrate protein antigen (CFP-10), TB10.4, and antigen 85A (Ag85A) and Ag85B (41- 45$)$. These were the first to be incorporated as antigens into subunit vaccines $(46,47)$. However, a recent unbiased, genome-wide analysis of CD4 T cell responses to $M$. tuberculosis antigens in adults with latent $M$. tuberculosis infection (LTBI) revealed that the human CD4 $\mathrm{T}$ cell response targets a very broad array of more than 80 antigens (48). These responses were predominantly restricted to CD4 $\mathrm{T}$ cells and highly enriched for a CXCR3+CCR6+ subset that exhibits Th1response characteristics (48). Nearly half of the epitopes identified in this study were derived from proteins that had not previously been identified as $\mathrm{T}$ cell antigens. This study and subsequent others demonstrate that the human immune response to $M$. tuberculosis is very heterogeneous and as yet poorly defined $(\underline{48-50})$. An intriguing question is whether $\mathrm{T}$ cell recognition of distinct $M$. $t u$ berculosis antigens is associated with TB disease risk.

Functional and phenotypic characteristics of $M$. tuberculosis-specific T cell responses have received par- 


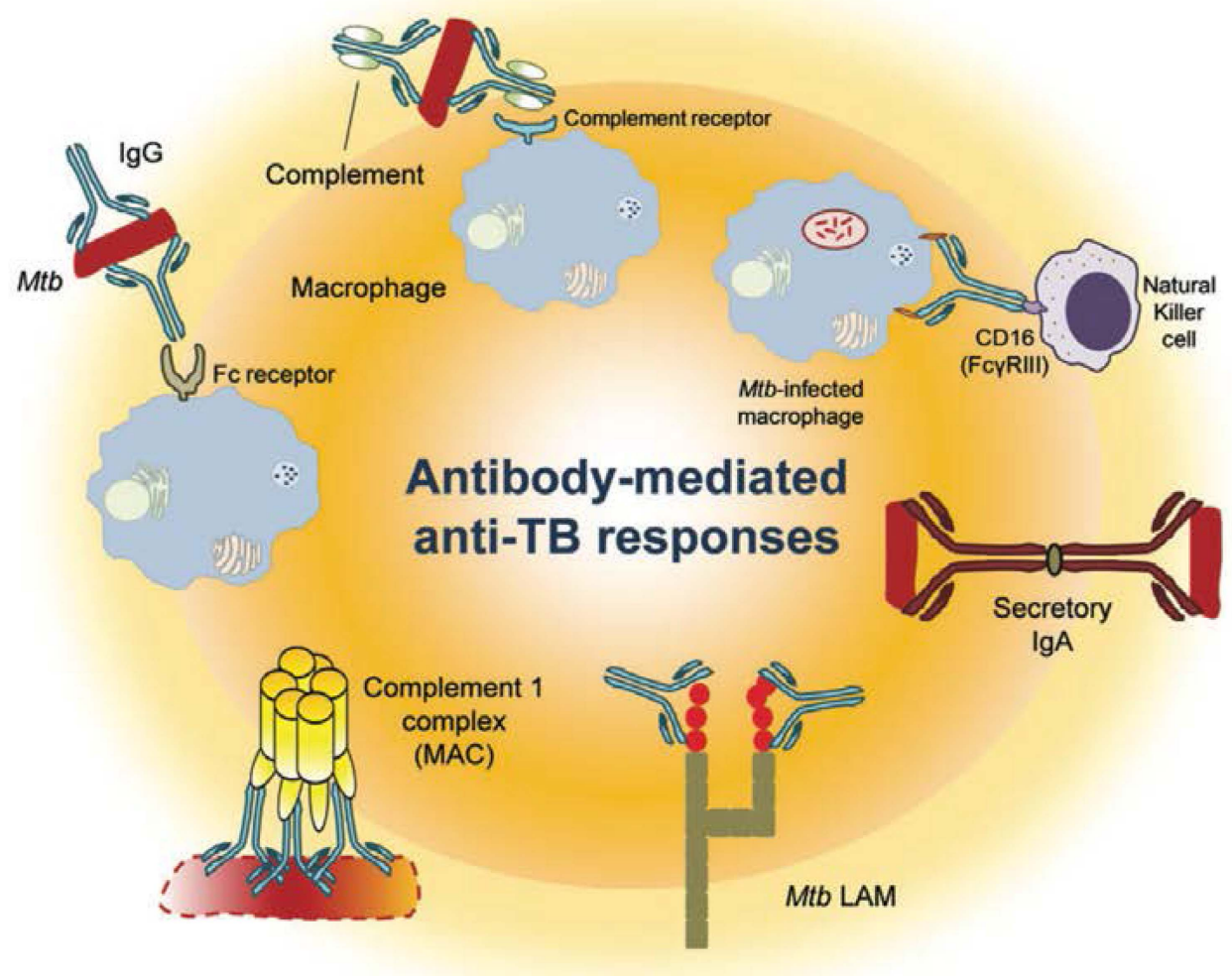

FIGURE 3 Role of antibodies in anti-M. tuberculosis (Mtb) infection. Antibodies may directly bind to mycobacteria, triggering complement deposition and lysis of $M$. tuberculosis, or complement may mediate opsonophagocytosis of the organism. Alternatively, M. tuberculosis-bound antibody may enhance macrophage uptake through Fc receptor binding or activate NK cell activity through Fc receptor engagement. It is also possible for immune complexes to form between mycobacterial antigen and antibody. Abbreviations: FcyRIII, Fc gamma receptor III; IgA, immunoglobulin A; IgG, immunoglobulin G; LAM, lipoarabinomannan; MAC, membrane-attack complex. (From reference $\underline{37}$ with permission.)

ticular attention in recent times, and interesting associations with the presentation of M. tuberculosis infection have been described. While the M. tuberculosis-specific $\mathrm{T}$ cell response in healthy people is dominated by CD4 $\mathrm{T}$ cells ( $(48)$, a number of studies have revealed an increased contribution by CD8 T cells in patients with TB disease (51-53). The mechanism for this finding is currently not clear, but this pattern appears robust and has been proposed as a diagnostic approach for TB disease (53).

A prominent theme has been the pattern of Th1 cytokine coexpression, shown to be associated with the degree of $\mathrm{T}$ cell differentiation in viral infections (54). Comparative studies of patients with TB disease and latently infected people have reported elevated frequencies of M. tuberculosis-specific CD4 T cells expressing only TNF or TNF+IFN- $\gamma+$ CD4 T cells in TB patients, while those with latent infection have higher frequencies of polyfunctional TNF+IFN- $\gamma+\mathrm{IL}-2+$ M. tuberculosis- specific CD4+ $\mathrm{T}$ cell responses $(\underline{51}, \underline{55}, 56)$. Furthermore, successful TB treatment appears to reverse this functional pattern, because CD4 T cells coexpress IFN- $\gamma$, TNF, and IL-2 to a greater degree after cure $(51, \underline{56})$. However, other studies have reported the opposite: active TB disease was accompanied by greater frequencies of polyfunctional TNF+IFN- $\gamma+\mathrm{IL}-2+\mathrm{CD} 4 \mathrm{~T}$ cells than was LTBI (57-59). An immune correlates study in bacillus Calmette-Guérin (BCG)-vaccinated infants aimed to determine whether frequencies or cytokine coexpression patterns of mycobacteria-specific Th1-cytokineexpressing CD4 or CD8 cells, measured at 10 weeks of age, were associated with subsequent risk of TB disease $(\underline{60})$. The study reported no association between frequencies or cytokine expression patterns in BCGspecific CD4 and CD8 T cells (61). However, more recently, BCG-specific IFN- $\gamma$-secreting T cells measured by enzyme-linked immunosorbent spot assay (ELIspot) 
were found to be associated with reduced risk of developing TB disease in a South African infant cohort from the same population (62).

Such functional differences in $\mathrm{T}$ cell cytokine expression may simply reflect differential levels of $\mathrm{T}$ cell exposure to $M$. tuberculosis antigens, indicating in vivo bacterial load (51). This hypothesis is supported by phenotypic analyses of M. tuberculosis-specific T cells, which suggest that higher bacterial load in active disease is associated with greater $\mathrm{T}$ cell activation.

Activation of antigen-specific CD4 T cells, measured by HLA-DR, CD38, or Ki67 expression, was significantly higher in patients with active TB compared to controls with LTBI (63). These activation markers seemed to track antigen load well, as expression levels gradually decreased during treatment of active disease, suggesting that $\mathrm{T}$ cell expression of these activation markers can be useful as treatment response markers (63). A recent study investigated $\mathrm{T}$ cell activation as a biomarker of risk of $\mathrm{TB}$ (see section on progression to TB disease).

\section{B cells and antibody responses}

Many studies have assessed the ability of antibodies to accurately diagnose active TB, and these studies will be discussed below. In some studies the ability of antibodies to differentiate M. tuberculosis-infected subjects (defined as either TST+ or IGRA+) and uninfected controls has also been assessed (Table 1). It is estimated that a third of the world's population is latently infected with M. tuberculosis, although this varies greatly from region to region (2) and latency is likely to represent a spectrum from transient exposure to subclinical TB disease (64). Analysis of antibodies in those with M. tuberculosis infection, approximately $90 \%$ of whom are able to contain infection, versus uninfected controls enables the identification of antibody responses that may be important in the control of M. tuberculosis infection. M. tuberculosis infection induces mycobacteria-specific antibodies against a broad range of antigens, with no single antigen or group of antigens emerging as a preferential target for an antibody response (Table 1). Mycobacterial antigen-specific $\operatorname{IgG}, \operatorname{IgA}$, and $\operatorname{IgM}$ have all been reported in M. tuberculosis infection (Table 1). Perley et al. report approximately equal ratios of $\operatorname{IgG}$ and IgM in response to live cell surface, whole cell lysate, lipoarabinomannan (LAM), and cell wall and secreted mycobacterial proteins in M. tuberculosisinfected and uninfected controls (65). There are few studies in HIV-infected populations and little evidence for elevation of mycobacterial antibodies in HIV- infected, M. tuberculosis-infected versus HIV-1-infected, M. tuberculosis-uninfected populations $(66,67)$. All studies agree that antibody levels in M. tuberculosis infection are highly variable, with a high degree of overlap between infected individuals and uninfected controls. The greatest separation between M. tuberculosis-infected and uninfected control populations was reported by Baumann et al. (68), who found discrimination between M. tuberculosis-infected (defined as IGRA+ or TST+) and uninfected controls with $80 \%$ sensitivity and 93\% specificity using $\mathrm{AlaDH}$ (Rv2780)-specific IgA, and $84.2 \%$ sensitivity and $93 \%$ specificity using NARL (Rv0844c)-specific IgA. In a separate study, they reported $74 \%$ sensitivity and $83 \%$ specificity using a combination of $\operatorname{IgA}$ and $\operatorname{IgG}$ specific for LAM and PE35 (Rv3872) (68). Perley et al. found better discrimination when measuring antibodies directed against the live cell surface of mycobacteria when compared to cell wall, LAM, or secreted proteins from M. tuberculosis ( $\underline{65})$.

T cell responses to $M$. tuberculosis-specific antigens, including ESAT-6 and CFP-10, are used as the basis for IGRAs to discriminate between $M$. tuberculosis-infected and uninfected individuals (30). However, antibody responses against $M$. tuberculosis-specific antigens are generally poor at discriminating between infected and uninfected individuals, although Hoff et al. found that they performed better in low-burden settings (69-72). It is important to note the potential bias because $M$. tuberculosis infection is defined by a cellular immune response measured by either TST reaction or IGRA response to an $M$. tuberculosis-specific antigen. There is currently no method that does not depend upon detection of a cell-mediated immune response for the detection of $M$. tuberculosis infection. While antibody responses are higher in those with a positive TST or IGRA, several studies have described high levels of M. tuberculosis antibodies in individuals with TST anergy, suggesting that antibodies can be elevated following M. tuberculosis exposure in the absence of a cellmediated immune response $(\underline{73}, \underline{74})$.

\section{BCG vaccination and antibodies}

A detectable increase in mycobacterial specific antibody is not always observed following BCG immunization $(\underline{75})$, most likely due to pre-existing high-titer antibody induced by exposure to environmental mycobacteria $(\underline{76}$, 77). BCG, however, has been found to induce modest levels of mycobacterial antigen-specific antibodies in several studies ( $\underline{78}-\underline{81})$. Higher levels of Ag85A IgG antibodies in 4- to 6-month-old South African infants vaccinated with BCG at birth were found to be 
TABLE 1 Antibodies in M. tuberculosis infection

\begin{tabular}{|c|c|c|c|c|c|}
\hline Author & Study design & $\begin{array}{l}\text { HIV-1 } \\
\text { pos/neg }\end{array}$ & $\begin{array}{l}\text { Class of } \\
\text { antibody }\end{array}$ & Antigen & $\begin{array}{l}\text { Detected difference }{ }^{a} \\
\text { (\% sensitivity; \% specificity) }\end{array}$ \\
\hline $\begin{array}{l}\text { Chen J et al., } 2010(\underline{70}) \\
\text { Baumann R et al., } 2015(\underline{68)}\end{array}$ & $\begin{array}{l}\text { LTBI versus controls (China) } \\
\text { LTBI versus controls } \\
\text { (South Africa) }\end{array}$ & $\begin{array}{l}\text { Neg } \\
\text { Neg }\end{array}$ & $\begin{array}{l}\lg G \\
\lg A \\
\lg A \\
\lg A \\
\lg A \\
\lg G \\
\lg A\end{array}$ & $\begin{array}{l}\text { Rv1985c } \\
\text { NARL (Rv0844c) } \\
\text { MPT83 (Rv2873) } \\
19 \text { kDa (Rv3763) } \\
\text { AlaDH (Rv2780) } \\
\text { AlaDH (Rv2780) } \\
\text { PstS3 (Rv0928) }\end{array}$ & $\begin{array}{l}62 ; 97 \\
84.2 ; 93 \\
63.2 ; 93 \\
78.9 ; 93 \\
89.5 ; 93 \\
26.3 ; 93 \\
\text { NS } \\
57.9\end{array}$ \\
\hline $\begin{array}{l}\text { Baumann R et al., } 2014 \\
\text { (222) }\end{array}$ & $\begin{array}{l}\text { LTBI versus controls } \\
\text { (South Africa) }\end{array}$ & Neg & $\begin{array}{l}\lg M, \lg A \\
\lg A, \lg G \\
\lg A, \lg G \\
\lg A, \lg G \\
\lg A, \lg G \\
\lg A\end{array}$ & $\begin{array}{l}\text { MPT32 (Rv1860) } \\
\text { PE35 (Rv3872) } \\
\text { LAM } \\
\text { Tpx (Rv1932) } \\
16 \text { kDa (Rv2031c) } \\
\text { HSP20 (Rv251c) }\end{array}$ & $\begin{array}{l}49 ; 100 \\
\text { IgA } \\
\text { PE35 + LAM } \\
74 ; 83 \\
\text { IgA and IgG combined } \\
\text { NS } \\
\text { NS } \\
\text { NS }\end{array}$ \\
\hline Niki M et al., 2015 (72) & $\begin{array}{l}\text { LTBI versus controls, } \\
\text { IGRA+ (Tokyo) }\end{array}$ & Neg & $\begin{array}{l}\lg G / \lg A \\
\lg G / \lg A \\
\lg G / \lg A \\
\lg G / \lg A \\
\lg G / \lg A \\
\lg G / \lg A \\
\lg G / \lg A\end{array}$ & $\begin{array}{l}\text { HrpA (Rv0251c/hsp) } \\
\text { MDP1 (Rv2986c) } \\
\text { ESAT-6 (Rv3875) } \\
\text { CFP-10 (Rv3874) } \\
\text { Ag85A (Rv3804c) } \\
16 \text { kDa (Rv2031c) } \\
\text { HBHA (Rv0475) }\end{array}$ & $\begin{array}{l}\operatorname{lgG}, P<0.01 \\
\lg A, P<0.05^{b} \\
\text { NS } \\
\text { NS } \\
\text { NS } \\
\text { NS } \\
\text { NS }\end{array}$ \\
\hline Hoff S et al., 2007 (69) & $\begin{array}{l}\text { Control versus LTBI } \\
\text { (Denmark, Brazil, Ethiopia, } \\
\text { Tanzania) }\end{array}$ & Neg & $\begin{array}{l}\lg G \\
\lg G \\
\lg G\end{array}$ & $\begin{array}{l}\text { ESAT-6-CFP10 fusion } \\
\text { Denmark } \\
\text { Brazil, Ethiopia }\end{array}$ & $\begin{array}{l}P<0.01 \\
P=0.043 \\
P=0.038\end{array}$ \\
\hline Perley CC et al., 2014 (65) & $\begin{array}{l}\text { Control versus } \\
\text { IGRA+ (U.S.) }\end{array}$ & Neg & $\begin{array}{l}\lg G \\
\lg G \\
\lg G \\
\lg G \\
\lg G \\
\lg G \\
\lg G \\
\lg G \\
\lg G \\
\lg G\end{array}$ & $\begin{array}{l}\text { Live cell surface } \\
\text { Whole cell lysate } \\
\text { IgG avidity, live cell surface } \\
\text { IgG avidity, whole cell lysate } \\
\text { LAM } \\
\text { Cell wall } \\
\text { Secreted proteins } \\
\text { IgG avidity, LAM } \\
\text { IgG avidity, cell wall } \\
\text { IgG avidity, secreted } \\
\text { proteins }\end{array}$ & $\begin{array}{l}P<0.001 \\
P<0.01 \\
P<0.05^{b} \\
\text { NS } \\
\text { NS } \\
\text { NS } \\
\text { NS } \\
P<0.05 \\
\text { NS } \\
P<0.001\end{array}$ \\
\hline
\end{tabular}

${ }^{a} \mathrm{NS}$, not significant.

${ }^{b}$ Decreased in LTBI. 
associated with reduced risk of developing $\mathrm{TB}$ disease over the next 3 years of life (62). BCG-induced antibodies may contribute toward a protective immune response through mechanisms including the opsonization of mycobacterial cells for uptake by phagocytes (2).

\section{Mechanisms of antibody action}

Kumar et al. found that treatment with sera from M. tuberculosis-infected, healthy subjects enhanced uptake and intracellular killing of mycobacteria by donor myeloid-derived macrophages (MDM). Interestingly, not all mycobacterial antigens opsonized mycobacteria, and two antigens with approximate molecular weights of 48 and $80 \mathrm{kDa}$ (possibly M. tuberculosis 48 and M. tuberculosis 81 ) were absent from opsonizing antibody extracts (83). Opsonized mycobacteria were killed more rapidly with enhanced IFN- $\gamma$ and IL- 6 production, enhanced phagosome acidification, and increased inducible nitric oxide synthase and nitric oxide production (83). The enhanced uptake of serum-coated mycobacteria by neutrophils and monocyte/macrophages was found to be IgG dependent in a separate study (2) .

\section{Antibody-inducing vaccines}

There are no TB vaccine candidates currently in clinical development that are designed for the specific enhancement of a B cell or antibody response, although whole-cell mycobacterial vaccines such as VPM1002 (recombinant BCG) (84) and VAC (attenuated M. tuberculosis) (5) will induce a broad-spectrum response including antibodies. It is possible to enhance antibody responses to subunit $\mathrm{TB}$ vaccines through the use of specific adjuvants (86). Alum is widely used for the induction of antibodies, although it also skews toward a Th2 type immune response and does not protect against $M$. tuberculosis (86). There are, however, adjuvants such as MF59 which induce both a Th1 type cellular response and antibody and have been shown to enhance protection in mice challenged with $M$. tuberculosis (므).

\section{PROGRESSION FROM M. TUBERCULOSIS INFECTION TO TB DISEASE}

Although most individuals who become infected with M. tuberculosis remain asymptomatic, in some the immune response fails to contain the infection and clinical symptoms develop, including fevers, night sweats, weight loss, and chronic coughing, among many others. Definitive diagnosis of TB disease is based on detection of acid-fast bacilli, most often in sputum from the patient. The risk of progression to disease is greatest immediately following infection $(\underline{87}, \underline{88})$; however, M. tuberculosis can persist for years in asymptomatic individuals. Long-term persistence of viable bacilli was reported in 1927, when M. tuberculosis was cultured from apparently healthy tissues of individuals with no pathological evidence of TB who died from other causes (89). Progression to active disease is possible even decades after exposure (8) and is typically triggered by immune compromise. This was elegantly demonstrated by reactivation of LTBI in rheumatoid arthritis patients who received anti-TNF blocking antibodies or other immunotherapies $(90,91)$. Many factors, including the magnitude of the infectious dose, the bacterial strain, time since exposure, and a multitude of other risk factors have been associated with risk of TB. Innate and adaptive immune mechanisms are clearly very important for successful control of $M$. tuberculosis, since impairment of immunity through steroids, chemotherapy, biologics, and HIV coinfection predisposes to TB disease (reviewed in reference 92).

\section{Immune Mediators of TB Risk}

TB susceptibility is driven by immune dysfunction, whether during acute or chronic latent stages of $M$. $t u$ berculosis infection. The control of infection requires a precise balance between immune-mediated eradication of M. tuberculosis and limitation of inflammation to prevent immunopathology. As such, it is thought that any immune dysfunction which tips the balance in either direction can lead to disease progression. Among the greatest risk factors for TB are HIV-1 infection, malnutrition, diabetes mellitus, smoking, vitamin $\mathrm{D}$ deficiency, drug/alcohol abuse, male gender, age, and antiTNF therapy (93-97). These risk factors are not mutually exclusive and can exacerbate each other (98-102). However, the phenotype of immunodeficiency induced by each is different, and therefore the interrelationship between comorbidities and disease susceptibility is complex. Studies of the underlying causes of each of these risk factors and their effects on TB risk can provide important insights into the mechanisms of protective immunity against $M$. tuberculosis in humans.

\section{HIV}

The resurgence of TB in sub-Saharan Africa is linked to the onset of the HIV-1 pandemic (103). Coinfection with HIV-1 is thought to increase susceptibility to TB via a number of mechanisms, primarily through dysfunctional and decreased numbers of CD4 T cells and impaired activation of $\mathrm{T}$ cell responses by phagocytes 
(100, 104-106). However, increased risk of TB typically occurs in HIV-infected individuals prior to significant $\mathrm{T}$ cell depletion (107), suggesting that HIV may alter cellular responses to M. tuberculosis infection. HIV-1 and M. tuberculosis coinfection of PBMCs or macrophages has been shown to synergistically increase replication of both pathogens in vitro $(108,109)$. M. tuberculosis infection induces HIV-1 replication via a number of mechanisms, including upregulating the transcription factors, NF- $\kappa B$ (108), nuclear factor of activated T cells5 (NFAT5), positive transcription elongation factor (P-TEFb), and loss of an inhibitory C/EBP $\beta$ (110-112). Induction of chemokines during $M$. tuberculosis infection also increases cellular recruitment of CCR5-positive monocytes and CD4 $\mathrm{T}$ cells into the site of infection, increasing the pool of cells that can be infected by HIV-1 (113). Conversely, the effect of HIV-1 on the macrophage response is variable and subtle, modifying cytokine and chemokine production required for $\mathrm{T}$ cell recruitment and activation $(109,114)$. In a large multicenter study in India, Lagrange et al. found higher levels and greater sensitivity for antibody-based TB diagnostic tests among HIV-positive compared to HIV-negative TB patients $(\underline{115})$. In HIV-positive TB, secretion of BCGspecific IgG antibodies from peripheral plasmablasts was higher than in HIV-negative TB, and it increased further as CD4 T cell counts declined (116). The higher levels of antibody in HIV-positive TB likely reflect increased systemic mycobacterial load. The interaction of HIV with M. tuberculosis susceptibility is discussed in detail in reference $\underline{117}$.

\section{Diabetes mellitus}

The link between type 2 diabetes mellitus (T2DM) and increased TB risk has long been recognized (118), but the immunological mechanisms are poorly understood. Up to $22 \%$ of TB cases are attributed to T2DM in countries where both conditions are endemic (119). Recent systematic reviews have shown that individuals with T2DM have a 3-fold greater risk of TB and increased risk of mortality, delayed sputum conversion, treatment failure, and relapse, as well as developing drug resistance due to T2DM, interfering with rifampin metabolism (120-124). TB patients with T2DM are also more likely to have cavitary TB (124), while HIV-1 decreases this risk (125). Therefore, while HIV-1 increases TB risk up to 50-fold (126), the increasing prevalence of T2DM could have a relatively greater impact on $\mathrm{TB}$ control in the future (127).

Two mechanisms underlying the T2DM-associated risk for $\mathrm{TB}$ have been hypothesized: (i) dysregulated glucose metabolism results in hyperglycemia and insulin resistance, enhancing $M$. tuberculosis replication, and (ii) increased inflammation by adipose-resident monocytes activated by free fatty acids and lipid intermediates, associated with insulin resistance, promotes a generalized proinflammatory environment that favors progression to TB disease $(118,128)$. In support of the second hypothesis, it has recently been shown that TB patients with T2DM have increased circulating Th1 (IFN- $\gamma$, TNF, IL-2), Th17 (IL-17A), and other proinflammatory (IL-1 $\beta$, IL-6, IL-18) cytokines, hyperreactive T-helper cells, and reduced frequencies of regulatory $\mathrm{T}$ cells (Tregs) (129-131). How T2DM-associated inflammation impacts TB susceptibility, TB immunopathology, and M. tuberculosis killing is unknown, but longitudinal studies investigating HbA1c levels in TB patients during TB treatment have shown that glucose intolerance decreases following successful TB treatment $(132,133)$. This suggests that in some cases T2DM may result from infection-induced impaired glucose metabolism, rather than prior T2DM increasing TB risk. Irrespective of the sequence of attainment, screening and treatment for glucose intolerance during TB are likely to improve treatment outcome.

\section{Vitamin D}

Vitamin D deficiency is common in active TB patients $(102,134)$, is exacerbated in TB patients with HIV-1, and is more prevalent in people with LTBI who progress to active TB (135). Furthermore, individuals who carry a vitamin $\mathrm{D}$ receptor (VDR) polymorphism at the Taq1 locus (rs731236) or the vitamin D binding protein Gc2 haplotype (T420K amino acid change) and are vitamin $\mathrm{D}$ deficient are more susceptible to TB $(134,136)$. The effects of vitamin $\mathrm{D}$ on the immune system are pleiotropic (137). Consequently, the exact mechanisms by which vitamin $\mathrm{D}$ may help prevent $\mathrm{TB}$ remain a subject of contention. Moreover, the unique antimicrobial effect of vitamin $\mathrm{D}$ metabolites, mediated by expression of cathelicidin antimicrobial peptide $(C A M P)$, is unique to humans (and other primates), who have evolved three vitamin $\mathrm{D}$ response elements in the CAMP promoter. These promoter elements are missing from rodents and cattle (138), species commonly studied as models of human TB.

Vitamin D has two modes of action. One is fastactivating via membrane VDR, increasing reactive oxygen species (139), nitric oxide (140), and phagolysosome fusion during mycobacterial infection (141). The other occurs via binding to the nuclear VDR, forming a transcription factor complex which targets more than 900 
promoters (142). VDR activation induces expression of cathelicidin (proteolytically cleaved into LL-37), which has direct antimycobacterial effects and also induces autophagy $(\underline{25}, 101,143)$. Vitamin D treatment also reduces matrix metalloproteinase (MMP) activity, which is linked to lung matrix degradation and chemokine processing $(144,145)$. Conversely, vitamin D drives the adaptive response toward an anti-inflammatory state, increasing IL-10 production and regulatory $\mathrm{T}$ cell differentiation and inhibiting proinflammatory cytokines (99, 146, 147). While a decrease in proinflammatory responses during initial infection is counterintuitive to a protective response, the anti-inflammatory effects of vitamin $\mathrm{D}$ are likely to enhance resolution of pathologic inflammation during TB treatment (148). The same may occur during initial infection, limiting excessive inflammation while enhancing antimycobacterial activity.

The antimicrobial effects of vitamin D metabolites have also been shown to be crucial for the protective activity of IFN- $\gamma$. We and others have shown that stimulating human monocytes and MDM with IFN- $\gamma$ in vitamin D-sufficient media prior to infection increased CAMP expression and autophagolysosomal fusion and reduced intracellular M. tuberculosis growth (149, 150). Conversely, pre- and postinfection treatment of MDM with IFN- $\gamma$ had no effect on vitamin D-mediated M. tuberculosis growth restriction when vitamin D metabolites were added postinfection (149). This suggests that maintaining vitamin $\mathrm{D}$ sufficiency prior to infection will enhance macrophage and T cell-mediated innate cell responses during $M$. tuberculosis infection.

\section{Malnutrition}

Malnutrition has historically been associated with peaks in TB incidence, but the direct effect of malnutrition on TB risk is ill-defined (151). Body mass index (BMI) and TB incidence have been demonstrated to have an inverse relationship, with a $13.8 \%$ reduction in TB per unit increase in BMI (152). Malnutrition can encompass both macronutrient and micronutrient deficiencies; however, the underlying interaction of each with host immunity to increase TB risk is poorly understood. Studies have shown that TB patients from various populations have deficiencies of vitamins $\mathrm{A}, \mathrm{C}, \mathrm{D}$, and $\mathrm{E}$, zinc, and iron (153). Vitamin D, being the most studied, has been described above. Recent evidence suggests that vitamin C has direct anti-M. tuberculosis activity, dependent on high ferrous ion levels and reactive oxygen species production (154). Vitamin A (retinol) deficiency is also associated with $\mathrm{TB}$ and may synergize with vitamin $\mathrm{D}$, as the retinol $\mathrm{X}$ receptor $\mathrm{RXR}$ forms a heterodimer with the VDR to form a transcription factor complex, and cotreatment with vitamin $\mathrm{D}_{3}$ plus retinoic acid inhibits M. tuberculosis entry and survival within macrophages, possibly through rescue of phagosome maturation arrest (155). Vitamin A, via its active metabolite all-trans retinoic acid, has recently been shown to induce myeloid cells to express $N P C 2$, which helps the cell effectively remove cholesterol from the lysosomes so M. tuberculosis bacteria cannot access it. This increases lysosome acidification and M. tuberculosis killing (156). Moreover, vitamin A adjunct therapy during intensive-phase TB treatment enhances sputum smear conversion (157).

\section{Inflammation and Progression to TB}

TB disease is a chronic inflammatory condition, and the pathology of the disease is a consequence of the host immune response to the mycobacterium, rather than direct destruction of tissue by M. tuberculosis itself. The balance of sufficient inflammation for containment of infection and immune pathology as a result of excessive inflammation is critical to our understanding of human TB disease. In 1891 Robert Koch reported results of a study in which he repeatedly injected TB patients with tuberculin (158). This treatment did not cure TB but, rather, induced inflammation, swollen lymph nodes, and tissue necrosis and in some patients resulted in death (158). In addition to the magnitude of the inflammatory response, the timing and location of the response are also likely to be key for the balance between control of infection and progression to active disease (reviewed in reference 33). While animal models have revealed the importance of individual cell types such as neutrophils, classically and alternatively activated macrophages, and specific cytokines such as IL-10 and TNF (159) in a balanced inflammatory response, it has been harder to understand these processes in human populations. Genetics can influence the inflammatory response, but the strongest driver of variability in the human inflammatory response appears to be our environment. In an immune phenotyping study, differences in immune cell populations were largely associated with environmental and not genetic factors, with cytomegalovirus identified as the major microbial driver of immune variation (160).

\section{Type I interferons in TB}

The type I interferon response is classically a response to viral infection, and yet human biomarker studies have identified IFN- $\alpha / \beta$ proinflammatory immune signatures as key components of active TB disease $(24,161-164)$. This response is likely driven by mycobacterial load 
because it associates with disease pathology and declines in response to TB treatment $(164,165)$. In vitro experiments show that type I interferons reduce the expression of IFN- $\gamma$ and the ability of macrophages to respond to IFN- $\gamma$ and control intracellular growth of M. tuberculosis (166). IL-1 can limit excessive type 1 interferon activity in mice, suggesting that this pathway could provide a target for host-directed therapy in TB (167).

\section{Monocytes in TB disease}

Monocytes are the primary target of mycobacterial growth among PBMCs infected in vitro, and in peripheral blood, monocyte numbers expand during active TB disease (168). In the 1930s it was recognized that the ratio of monocytes to lymphocytes in peripheral blood may be important for the resistance or susceptibility to TB disease. During healing of lesions, an increase of lymphocytes around the granuloma has also been detected, and this correlated with an increase in lymphocyte:monocytes in the periphery (169).

Monocytes can be phenotypically and functionally distinct and can differentiate into M1 or M2 macrophages with pro- and anti-inflammatory properties, respectively, although this bipolar nomenculature is becoming more contentious with the increasing emergence of more polarization states which are relative to the activation agent $(170)$. CD16+ "inflammatory" monocytes have recently been shown to modulate immunity to mycobacteria through the production of IL-10 (171). Monocytes can also modulate immunity through amino acid catabolism, in particular tryptophan and arginine, through the induction of indoleamine 2,3-dioxygenase and arginase (reviewed in reference 172). T cells are sensitive to amino acid levels in the microenvironment, and depletion of arginine and tryptophan can result in T cell anergy. Increased ratios of monocytes in peripheral blood are associated with increased type I interferon-related transcript signatures and a reduction in ability to inhibit mycobacterial growth (173). The frequency of monocytes relative to lymphocytes has also been associated with risk of progression to TB disease (174-177). Typically, M1 macrophages are associated with killing of mycobacteria, whereas M2 macrophages are associated with tissue repair and bacterial persistence $(178,179)$. Therefore, in addition to monocyte quantity, the polarization state of monocytes is likely important for maintenance of balance in the inflammatory response in TB disease.

\section{Tissue Remodeling}

The ability of $M$. tuberculosis to induce degradation of pulmonary extracellular matrix (ECM) contributes to its success as a pathogen. Induction of lung cavitation allows bacilli to replicate in an immunologically privileged site, promoting persistence and transmission, while penetration of the alveolar basement membrane allows extrapulmonary dissemination of infection. MMPs, a family of zinc- and calcium-dependent endopeptidases, are capable of degrading all components of the pulmonary ECM. Moreover, MMPs also regulate the innate immune response by controlling cytokine and chemokine processing, apoptosis, and antimicrobial peptide activation (for review, see reference 180). These potent enzymes are expressed by a wide variety of cells, including lymphocytes, resting monocytes, and activated macrophages. MMP-1 (interstitial collagenase) and MMP-9 (92-kDa gelatinase B) are the major secreted MMPs of human monocytes and alveolar macrophages under basal conditions (181). M. tuberculosis induces expression of $M M P-1, M M P-7$, and $M M P-10$ in infected human macrophages $(144,182)$, and increased expression of MMP-1, MMP-7, and MMP-9 has also been demonstrated in cells isolated from the lungs of TB patients. MMP-1 and MMP-7 have been shown to colocalize to macrophages around the central area of necrosis in tuberculous granulomata $(182,183)$. M. tuberculosis-induced MMP-1, MMP-7, and MMP-9 secretion by mononuclear phagocytes has been shown to be prostaglandin E2 (PGE2) dependent (182, 184, 185), and IL-4 and IL-10 can inhibit monocyte secretion of MMP-1, MMP-7, and MMP-9 (184, 186, 187). Together this suggests that inhibiting MMP production though reduced PGE2 signaling may limit cavitation and potentially resolve pulmonary pathology during treatment.

\section{T Cell Responses during TB}

A recent analysis of immune correlates in infants who participated in the recent Phase IIb efficacy trial of MVA85A (188) suggests that elevated CD4 T cell activation is associated with risk of TB. Infants who developed TB disease during follow-up in the trial had significantly higher levels of total CD4 T cells expressing HLA-DR at study baseline than infants who remained healthy (62). Importantly, this association was replicated in an independent cohort, M. tuberculosis-infected adolescents, in whom elevated CD4 $\mathrm{T}$ cell activation was also found to correlate with risk of TB (62).

Positive TST or IGRA tests can spontaneously revert to negative (reviewed in reference 10). Reversion has been reported in many studies throughout the last century at rates of 10 to $50 \%$ (189-194). The mechanisms of reversion are not understood, and immune suppres- 
sion, egress of M. tuberculosis-specific T cells from the peripheral blood to sites of infection, or decreases in bacillary load are possible underlying causes. However, TST or IGRA reversion may also be indicative of clearance of M. tuberculosis infection. The most comprehensive study of TST reversion was performed in the 1920s in household contacts of TB cases (193). Among household contacts with at least two TSTs, $11.1 \%$ reverted from positive to negative. These TST reverters had a very low risk of active TB over the subsequent 5 years $(0.72 \%)$. By contrast, $23.3 \%$ of the entire cohort developed disease. The largest study of Quantiferon Gold In-Tube (QFT) reversion was performed in South African adolescents, in whom annual reversion rates of $5.1 \%$ were reported (189). Although the number of TB cases was too low for robust stratification of disease risk in this study, incident TB was 8-fold higher among QFT reverters than among individuals with consistently negative QFT results (1.47 versus 0.18 cases/ 100 person-years) (189). Additional studies are necessary to establish the clinical significance of TST and IGRA reversion.

\section{B Cells and TB Antibody Responses}

Although antibodies are induced against a broad range of protein and nonprotein antigens in active TB disease, they are not useful for diagnosis due to a lack of sensitivity and specificity. There is evidence for reduced antibody avidity in active TB disease and for perturbation in $\mathrm{Fc}$ receptor expression, suggesting that phagocytosis and antibody-mediated cellular cytotoxicity could be dysregulated. Transcriptomic signatures for B cells are also depressed in $\mathrm{TB}$, suggesting downregulation or exhaustion of the $\mathrm{B}$ cell response. $\mathrm{B}$ cells and antibodies are involved in the immune response to $\mathrm{TB}$, and the interaction of antibodies with phagocytic cells through Fc receptor engagement is emerging as a key area for research.

The quantity of antibody produced during M. tuberculosis infection is related to bacterial load, and higher antibody responses are observed in those at risk of disease and are correlated with mycobacterial load during disease (195). This suggests that antibodies are important in the control of active TB disease and has also led to the development of antibody-based assays for TB diagnosis. Antibody-based diagnostic assays are cheap to produce and amenable to development as point-ofcare tests which can be used in remote settings because they do not require specialist equipment. Much effort has been invested in developing an antibody-based assay for TB diagnosis, with limited success (196). In a sys- tematic review and meta-analysis of the literature, which included 67 studies amounting to 5,147 participants, the sensitivity was 0 to $100 \%$ and specificity was 31 to $100 \%$ (196). It was concluded that antibody assays produce inconsistent and inaccurate results, and these data were used to inform a World Health Organization policy statement against the use of serological tests (http:// whqlibdoc.who.int/publications/2011/9789241502054 _eng.pdf).

However, poor performance of antibodies as a diagnostic test does not translate to lack of importance in immune control of TB disease. This section discusses evidence from human studies of a role for antibodies in the control of TB disease.

\section{Antibody quality}

The primary purpose of antibody measurement in human studies has been the diagnosis of TB disease, and most studies focus on the quantity of antibody detected and not antibody quality. Antibody avidity is variable in TB patients (197) and shortly following TB treatment there is an increase in antibody quantity and a decrease in avidity, suggesting exhaustion of the $B$ cell response (198). Perley et al. found a decrease in avidity of antibody specific for the live cell surface of mycobacteria in TB patients, suggesting conversion of antibodies to lowavidity $\operatorname{IgG}$ or B cell exhaustion (65). Antibody avidity was also higher in those previously immunized with BCG, which raises the possibility of using vaccination to improve antibody avidity as a potential mechanism for protection against TB.

\section{Antibody function}

Given the extensive literature on antibody quantity in $\mathrm{TB}$, there are few studies assessing antibody function using clinical samples. It is known that complement binds efficiently to the surface of mycobacteria and that the classical, lectin, and alternative complement pathways are activated $(\underline{15}, 199)$. Preincubation with human serum containing mycobacterial specific IgG and IgM further enhances complement binding to mycobacteria (200). The ability of human sera to enhance uptake of mycobacteria into the macrophage is retained after heat treatment to inactivate complement, suggesting that uptake of mycobacteria also occurs via engagement of Fc gamma receptors on the phagocyte cell surface (83). Fc gamma receptor expression has consistently been identified in active TB disease biomarker studies with decreased expression in TB disease, indicating that downregulation of $\mathrm{Fc}$ gamma receptor may play a role in pathogenesis of TB disease $(\underline{161}, \underline{162}, \underline{201}, \underline{202})$. 


\section{BIOMARKERS IN HUMAN TB}

A major limitation of IGRA tests and TST is their inability to differentiate between LTBI and active TB disease (reviewed in reference 203). These tests cannot predict risk for progression to TB disease (30). Moreover, whole-blood transcriptomic signatures comparing TB, LTBI, and healthy controls support the recent change in dogma that LTBI represents a spectrum of disease states (Fig. 1), rather than a single clinical stage (204, 205). An important finding from whole-blood transcriptional profiling is that the gene expression signatures of some individuals clinically classified as LTBI cluster with the signature of active TB patients. These data suggest that these asymptomatic individuals may have subclinical TB disease $(24,206)$.

A biomarker that accurately identifies those at high risk for progression would allow targeted preventive antimicrobial therapy to prevent TB disease. This would be especially useful in settings of TB endemicity, where treating all latently infected people for 6 to 9 months is not feasible. Many investigators are therefore engaged in projects aimed at identifying correlates of risk of TB. The first study to report an association between gene expression in peripheral blood cells and risk of TB disease compared $15 \mathrm{HIV}$-infected drug users who ultimately progressed to active TB with 16 who remained disease free. Expression of two transcripts, IL-13 and AIRE, was found to correlate with risk of TB (207).

\section{Transcriptomic Profiling}

The unprecedented increase in our understanding of the human immune response to M. tuberculosis in the past decade is largely attributed to studies using wholegenome transcriptional profiling during various stages of pathogenesis and treatment (reviewed in reference 208). In general, these studies have characterized gene expression in whole blood. While these studies have been able to identify biomarkers with impressive diagnostic sensitivity for active $\mathrm{TB}$, it is not possible to infer correlates of protection against disease from such crosssectional study designs. To learn about mechanisms that underlie protective responses or progression from infection to disease, longitudinal studies in which individuals transition from LTBI to active TB are necessary. Three recent studies with such longitudinal designs have been completed. The first two were in BCG-vaccinated infants, and the results are discussed in the $\mathrm{T}$ cell and antibody sections above. The third was a large cohort study of 6,363 adolescents, half of whom were M. tuberculosis infected, who were followed up for 2 years. Incident TB disease was diagnosed during follow-up in 47 adolescents
(209). A prominent IFN response signature distinguished asymptomatic, HIV-uninfected persons who progressed to TB disease from those who remained asymptomatic. An additional fourth study adopted an alternate study design using PET/CT imaging of HIV-infected individuals with $M$. tuberculosis infection to identify those with sublinical TB and those at risk of TB (210). In those with underlying HIV infection, IFN response signatures did not readily discriminate between persons with subclinical TB and controls, most likely because HIV infection leads to increased expression of interferon transcripts in peripheral blood (H. Esmail, personal communication). This suggests that discriminating interferon signatures for TB risk may perform with reduced accuracy as predictive biomarkers of disease risk in HIV-infected individuals. However, additional signatures implicating myeloid inflammation and complement components were also identified as correlates of TB risk in both studies. It is clear that more such studies are required to delve deeper into the processes that underlie the transitions between the stages of M. tuberculosis infection in HIV-infected and uninfected individuals.

\section{Treatment Response}

A large number of studies across various populations have investigated serum biomarkers of $\mathrm{TB}$ and their response during therapy. In addition to the classical acute-phase markers C-reactive protein (CRP), serum amyloid A (SAA), and albumin, other highly regulated proteins in TB which change during TB therapy include CXCL9, CXCL10, S100A9, MMP1, MMP9, D-dimer, PGE-2, HGF, VEGF, and sIL-2R (148, 211, 212). Serum markers that can predict fast versus slow response to therapy have also been identified in multiple studies. However, performance of these biomarkers varies depending on the cohort and the cut-off used to define fast response. Some of the most consistent markers include CRP, SAA, sTNF-R1, sIL-2R, and neutrophil-associated proteins, including granzyme B and MMP1 (27, 213216). Ethnic genetic variation has been identified as a key variable affecting the performance of biomarkers of TB response (149), a finding that should be considered if protein biomarkers are to be used in $\mathrm{TB}$ diagnosis and the monitoring of therapy.

The measurement of antibody levels during TB drug treatment has been inconsistent, with some studies reporting a decline in antibody over time of treatment and others finding that antibody levels rise or do not change $(217,218)$. As described above, biomarker studies have identified changes in Fc gamma receptor expression in active TB disease $(\underline{164}, \underline{219})$. 
Transcriptomic signatures associated with B cells and humoral immunity have also been identified in biomarker studies focused on the response to TB treatment (164). Gene signatures associated with B cells are initially depressed and rise through therapy. This suggests that $\mathrm{B}$ cells are depleted or less functional during active disease, which is consistent with the observation of reduced antibody avidity in active TB (65).

\section{CONCLUSION}

Remarkable advances in our understanding of the immune response have been made since the advent of molecular biology and modern immunology. Among the themes are the incredible heterogeneity in infection states, disease presentation, and the complexity of the host response to M. tuberculosis. However, the exact immune mechanisms that underlie protective immunity against $M$. tuberculosis in humans remain unknown. Continued concerted research efforts and application of modern technologies are likely to enhance our understanding of the immunopathogenesis of TB in humans and facilitate rational development of highly effective interventions.

\section{REFERENCES}

1. Gagneux S. 2012. Host-pathogen coevolution in human tuberculosis. Philos Trans R Soc Lond B Biol Sci 367:850-859. http://dx.doi.org /10.1098/rstb.2011.0316

2. Dye C, Scheele S, Dolin P, Pathania V, Raviglione MC. 1999. Consensus statement. Global burden of tuberculosis: estimated incidence, prevalence, and mortality by country. WHO Global Surveillance and Monitoring Project. JAMA 282:677-686. http://dx.doi.org/10.1001/jama $\underline{.282 .7 .677}$

3. Wallgren A. 1948. The time-table of tuberculosis. Tubercle 29:245251. http://dx.doi.org/10.1016/S0041-3879(48)80033-4

4. Chen S, Chen J, Chen L, Zhang Q, Luo X, Zhang W. 2013. Mycobacterium tuberculosis infection is associated with the development of erythema nodosum and nodular vasculitis. PLoS One 8:e62653. http://dx .doi.org/10.1371/journal.pone.0062653

5. Mert A, Kumbasar H, Ozaras R, Erten S, Tasli L, Tabak F, Ozturk R. 2007. Erythema nodosum: an evaluation of 100 cases. Clin Exp Rheumatol 25:563-570.

6. Nicol MP, Kampmann B, Lawrence P, Wood K, Pienaar S, Pienaar D, Eley B, Levin M, Beatty D, Anderson ST. 2007. Enhanced anti-mycobacterial immunity in children with erythema nodosum and a positive tuberculin skin test. J Invest Dermatol 127:2152-2157. http://dx.doi.org /10.1038/sj.jid.5700845

7. Méchaï F, Soler C, Aoun O, Fabre M, Mérens A, Imbert P, Rapp C. 2011. Primary Mycobacterium bovis infection revealed by erythema nodosum. Int J Tuberc Lung Dis 15:1131-1132. http://dx.doi.org/10.5588 /ijtld.10.0582

8. Mahan CS, Zalwango S, Thiel BA, Malone LL, Chervenak KA, Baseke J, Dobbs D, Stein CM, Mayanja H, Joloba M, Whalen CC, Boom WH. 2012. Innate and adaptive immune responses during acute $M$. $t u$ berculosis infection in adult household contacts in Kampala, Uganda. Am J Trop Med Hyg 86:690-697. http://dx.doi.org/10.4269/ajtmh $\underline{.2012 .11-0553}$
9. Stein CM, Zalwango S, Malone LL, Won S, Mayanja-Kizza H, Mugerwa RD, Leontiev DV, Thompson CL, Cartier KC, Elston RC, Iyengar SK, Boom WH, Whalen CC, Mugerwa RD, Routy JP, Leontiev DV, Sekaly RP, Thompson CL, Cartier KC, Elston RC, Iyengar SK, Boom WH, Whalen CC. 2008. Genome scan of M. tuberculosis infection and disease in Ugandans. PLoS One 3:e4094. http://dx.doi.org/10.1371 /journal.pone.0004094

10. Hawn TR, Day TA, Scriba TJ, Hatherill M, Hanekom WA, Evans TG, Churchyard GJ, Kublin JG, Bekker L-G, Self SG. 2014. Tuberculosis vaccines and prevention of infection. Microbiol Mol Biol Rev 78:650-671. http://dx.doi.org/10.1128/MMBR.00021-14

11. Hirsch CS, Ellner JJ, Russell DG, Rich EA. 1994. Complement receptor-mediated uptake and tumor necrosis factor-alpha-mediated growth inhibition of Mycobacterium tuberculosis by human alveolar macrophages. J Immunol 152:743-753.

12. Keane J, Balcewicz-Sablinska MK, Remold HG, Chupp GL, Meek BB, Fenton MJ, Kornfeld H. 1997. Infection by Mycobacterium tuberculosis promotes human alveolar macrophage apoptosis. Infect Immun 65:298304.

13. Engele M, Stössel E, Castiglione K, Schwerdtner N, Wagner M, Bölcskei P, Röllinghoff M, Stenger S. 2002. Induction of TNF in human alveolar macrophages as a potential evasion mechanism of virulent $M y$ cobacterium tuberculosis. J Immunol 168:1328-1337. http://dx.doi.org /10.4049/jimmunol.168.3.1328

14. Silver RF, Walrath J, Lee H, Jacobson BA, Horton H, Bowman MR, Nocka K, Sypek JP. 2009. Human alveolar macrophage gene responses to Mycobacterium tuberculosis strains H37Ra and H37Rv. Am J Respir Cell Mol Biol 40:491-504. http://dx.doi.org/10.1165/rcmb.2008-0219OC

15. Hirsch CS, Ellner JJ, Russell DG, Rich EA. 1994. Complement receptor-mediated uptake and tumor necrosis factor-alpha-mediated growth inhibition of Mycobacterium tuberculosis by human alveolar macrophages. J Immunol 152:743-753.

16. Lala S, Dheda K, Chang JS, Huggett JF, Kim LU, Johnson MA, Rook GA, Keshav S, Zumla A. 2007. The pathogen recognition sensor, NOD2, is variably expressed in patients with pulmonary tuberculosis. BMC Infect Dis 7:96. http://dx.doi.org/10.1186/1471-2334-7-96

17. Juárez E, Carranza C, Hernández-Sánchez F, León-Contreras JC, Hernández-Pando R, Escobedo D, Torres M, Sada E. 2012. NOD2 enhances the innate response of alveolar macrophages to Mycobacterium tuberculosis in humans. Eur J Immunol 42:880-889. http://dx.doi.org /10.1002/eji.201142105

18. Rivas-Santiago B, Hernandez-Pando R, Carranza C, Juarez E, Contreras JL, Aguilar-Leon D, Torres M, Sada E. 2008. Expression of cathelicidin LL-37 during Mycobacterium tuberculosis infection in human alveolar macrophages, monocytes, neutrophils, and epithelial cells. Infect Immun 76:935-941. http://dx.doi.org/10.1128/IAI.01218-07

19. Tsao TC, Hong J, Huang C, Yang P, Liao SK, Chang KS. 1999. Increased TNF-alpha, IL-1 beta and IL-6 levels in the bronchoalveolar lavage fluid with the upregulation of their mRNA in macrophages lavaged from patients with active pulmonary tuberculosis. Tuber Lung Dis 79:279-285. http://dx.doi.org/10.1054/tuld.1999.0215

20. Huang KH, Wang CH, Lee KY, Lin SM, Lin CH, Kuo HP. 2013. NF$\kappa \mathrm{B}$ repressing factor inhibits chemokine synthesis by peripheral blood mononuclear cells and alveolar macrophages in active pulmonary tuberculosis. PLoS One 8:e77789. http://dx.doi.org/10.1371/journal.pone.0077789 21. Gleeson LE, Sheedy FJ, Palsson-McDermott EM, Triglia D, O’Leary SM, O'Sullivan MP, O'Neill LA, Keane J. 2016. Cutting Edge: Mycobacterium tuberculosis induces aerobic glycolysis in human alveolar macrophages that is required for control of intracellular bacillary replication. J Immunol 196:2444-2449. http://dx.doi.org/10.4049/jimmunol.1501612

22. Barnes PF, Leedom JM, Chan LS, Wong SF, Shah J, Vachon LA, Overturf GD, Modlin RL. 1988. Predictors of short-term prognosis in patients with pulmonary tuberculosis. J Infect Dis 158:366-371. http://dx .doi.org/10.1093/infdis/158.2.366 
23. Lowe DM, Bandara AK, Packe GE, Barker RD, Wilkinson RJ, Griffiths CJ, Martineau AR. 2013. Neutrophilia independently predicts death in tuberculosis. Eur Respir J 42:1752-1757. http://dx.doi.org $\underline{\text { /10.1183/09031936.00140913 }}$

24. Berry MP, Graham CM, McNab FW, Xu Z, Bloch SA, Oni T, Wilkinson KA, Banchereau R, Skinner J, Wilkinson RJ, Quinn C, Blankenship D, Dhawan R, Cush JJ, Mejias A, Ramilo O, Kon OM, Pascual V, Banchereau J, Chaussabel D, O'Garra A. 2010. An interferoninducible neutrophil-driven blood transcriptional signature in human tuberculosis. Nature 466:973-977. http://dx.doi.org/10.1038/nature09247 25. Martineau AR, Newton SM, Wilkinson KA, Kampmann B, Hall BM, Nawroly N, Packe GE, Davidson RN, Griffiths CJ, Wilkinson RJ. 2007. Neutrophil-mediated innate immune resistance to mycobacteria. J Clin Invest 117:1988-1994. http://dx.doi.org/10.1172/JCI31097

26. Ramos-Kichik V, Mondragón-Flores $\mathrm{R}$, Mondragón-Castelán $\mathrm{M}$, Gonzalez-Pozos S, Muñiz-Hernandez S, Rojas-Espinosa O, ChacónSalinas R, Estrada-Parra S, Estrada-García I. 2009. Neutrophil extracellular traps are induced by Mycobacterium tuberculosis. Tuberculosis (Edinb) 89:29-37. http://dx.doi.org/10.1016/j.tube.2008.09.009

27. Coussens AK, Wilkinson RJ, Nikolayevskyy V, Elkington PT, Hanifa Y, Islam K, Timms PM, Bothamley GH, Claxton AP, Packe GE, Darmalingam M, Davidson RN, Milburn HJ, Baker LV, Barker RD, Drobniewski FA, Mein CA, Bhaw-Rosun L, Nuamah RA, Griffiths CJ, Martineau AR. 2013. Ethnic variation in inflammatory profile in tuberculosis. PLoS Pathog 9:e1003468. http://dx.doi.org/10.1371/journal.ppat .1003468

28. Krupa A, Fol M, Dziadek BR, Kepka E, Wojciechowska D, Brzostek A, Torzewska A, Dziadek J, Baughman RP, Griffith D, Kurdowska AK. 2015. Binding of CXCL8/IL-8 to Mycobacterium tuberculosis modulates the innate immune response. Mediators Inflamm 2015:124762. http://dx .doi.org/10.1155/2015/124762

29. Park H, Li Z, Yang XO, Chang SH, Nurieva R, Wang YH, Wang Y, Hood L, Zhu Z, Tian Q, Dong C. 2005. A distinct lineage of CD4 T cells regulates tissue inflammation by producing interleukin 17. Nat Immunol 6:1133-1141. http://dx.doi.org/10.1038/ni1261

30. Pai M, Denkinger CM, Kik SV, Rangaka MX, Zwerling A, Oxlade O, Metcalfe JZ, Cattamanchi A, Dowdy DW, Dheda K, Banaei N. 2014. Gamma interferon release assays for detection of Mycobacterium tuberculosis infection. Clin Microbiol Rev 27:3-20. http://dx.doi.org/10.1128 /CMR.00034-13

31. Hunter RL. 2016. Tuberculosis as a three-act play: a new paradigm for the pathogenesis of pulmonary tuberculosis. Tuberculosis (Edinb) 97:817. http://dx.doi.org/10.1016/j.tube.2015.11.010

32. Hunter RL. 2011. Pathology of post primary tuberculosis of the lung: an illustrated critical review. Tuberculosis (Edinb) 91:497-509. http://dx .doi.org/10.1016/j.tube.2011.03.007

33. Dorhoi A, Kaufmann SH. 2014. Perspectives on host adaptation in response to Mycobacterium tuberculosis: modulation of inflammation. Semin Immunol 26:533-542. http://dx.doi.org/10.1016/j.smim.2014.10.002

34. Chan J, Mehta S, Bharrhan S, Chen Y, Achkar JM, Casadevall A, Flynn J. 2014. The role of B cells and humoral immunity in Mycobacterium tuberculosis infection. Semin Immunol 26:588-600. http://dx.doi .org/10.1016/j.smim.2014.10.005

35. Achkar JM, Chan J, Casadevall A. 2015. B cells and antibodies in the defense against Mycobacterium tuberculosis infection. Immunol Rev 264:167-181. http://dx.doi.org/10.1111/imr.12276

36. du Plessis WJ, Walzl G, Loxton AG. 2016. B cells as multi-functional players during Mycobacterium tuberculosis infection and disease. Tuberculosis (Edinb) 97:118-125 https://www.ncbi.nlm.nih.gov/pubmed 126611659

37. Rao M, Valentini D, Poiret T, Dodoo E, Parida S, Zumla A, Brighenti S, Maeurer M. 2015. B in TB: B cells as mediators of clinically relevant immune responses in tuberculosis. Clin Infect Dis 61(Suppl 3):S225-S234. http://dx.doi.org/10.1093/cid/civ614
38. Sebina I, Biraro IA, Dockrell HM, Elliott AM, Cose S. 2014. Circulating B-lymphocytes as potential biomarkers of tuberculosis infection activity. PLoS One 9:e106796. http://dx.doi.org/10.1371/journal.pone .0106796

39. Hoff ST, Salman AM, Ruhwald M, Ravn P, Brock I, Elsheikh N, Andersen P, Agger EM. 2015. Human B cells produce chemokine CXCL10 in the presence of Mycobacterium tuberculosis specific T cells. Tuberculosis (Edinb) 95:40-47. http://dx.doi.org/10.1016/j.tube.2014 .10 .005

40. Zhu Q, Zhang M, Shi M, Liu Y, Zhao Q, Wang W, Zhang G, Yang L, Zhi J, Zhang L, Hu G, Chen P, Yang Y, Dai W, Liu T, He Y, Feng G, Zhao G. 2016. Human B cells have an active phagocytic capability and undergo immune activation upon phagocytosis of Mycobacterium tuberculosis. Immunobiology 221:558-567. http://dx.doi.org/10.1016/j.imbio.2015 .12 .003

41. Covert BA, Spencer JS, Orme IM, Belisle JT. 2001. The application of proteomics in defining the T cell antigens of Mycobacterium tuberculosis. Proteomics 1:574-586. http://dx.doi.org/10.1002/1615-9861(200104) 1:4<574::AID-PROT574>3.0.CO;2-8

42. Boesen H, Jensen BN, Wilcke T, Andersen P. 1995. Human T-cell responses to secreted antigen fractions of Mycobacterium tuberculosis. Infect Immun 63:1491-1497.

43. Wilkinson KA, Wilkinson RJ, Pathan A, Ewer K, Prakash M, Klenerman P, Maskell N, Davies R, Pasvol G, Lalvani A. 2005. Ex vivo characterization of early secretory antigenic target 6 -specific $T$ cells at sites of active disease in pleural tuberculosis. Clin Infect Dis 40:184-187. http://dx.doi.org/10.1086/426139

44. Lalvani A, Nagvenkar P, Udwadia Z, Pathan AA, Wilkinson KA, Shastri JS, Ewer K, Hill AV, Mehta A, Rodrigues C. 2001. Enumeration of $\mathrm{T}$ cells specific for RD1-encoded antigens suggests a high prevalence of latent Mycobacterium tuberculosis infection in healthy urban Indians. J Infect Dis 183:469-477. http://dx.doi.org/10.1086/318081

45. Pathan AA, Wilkinson KA, Klenerman P, McShane H, Davidson RN, Pasvol G, Hill AV, Lalvani A. 2001. Direct ex vivo analysis of antigenspecific IFN-gamma-secreting CD4 T cells in Mycobacterium tuberculosisinfected individuals: associations with clinical disease state and effect of treatment. J Immunol 167:5217-5225. http://dx.doi.org/10.4049 ljimmunol.167.9.5217

46. McShane H, Pathan AA, Sander CR, Keating SM, Gilbert SC, Huygen K, Fletcher HA, Hill AV. 2004. Recombinant modified vaccinia virus Ankara expressing antigen 85A boosts BCG-primed and naturally acquired antimycobacterial immunity in humans. Nat Med 10:1240-1244. http://dx.doi.org/10.1038/nm1128

47. Abel B, Tameris M, Mansoor N, Gelderbloem S, Hughes J, Abrahams D, Makhethe L, Erasmus M, de Kock M, van der Merwe L, Hawkridge A, Veldsman A, Hatherill M, Schirru G, Pau MG, Hendriks J, Weverling GJ, Goudsmit J, Sizemore D, McClain JB, Goetz M, Gearhart J, Mahomed H, Hussey GD, Sadoff JC, Hanekom WA. 2010. The novel tuberculosis vaccine, AERAS-402, induces robust and polyfunctional CD4+ and CD8+ $\mathrm{T}$ cells in adults. Am J Respir Crit Care Med 181:1407-1417. http://dx .doi.org/10.1164/rccm.200910-1484OC

48. Lindestam Arlehamn CS, Gerasimova A, Mele F, Henderson R, Swann J, Greenbaum JA, Kim Y, Sidney J, James EA, Taplitz R, McKinney DM, Kwok WW, Grey H, Sallusto F, Peters B, Sette A. 2013. Memory T cells in latent Mycobacterium tuberculosis infection are directed against three antigenic islands and largely contained in a CXCR3+CCR6+ Th1 subset. PLoS Pathog 9:e1003130. http://dx.doi.org/10.1371/journal.ppat .1003130

49. Carpenter C, Sidney J, Kolla R, Nayak K, Tomiyama H, Tomiyama C, Padilla OA, Rozot V, Ahamed SF, Ponte C, Rolla V, Antas PR, Chandele A, Kenneth J, Laxmi S, Makgotlho E, Vanini V, Ippolito G, Kazanova AS, Panteleev AV, Hanekom W, Mayanja-Kizza H, Lewinsohn D, Saito M, McElrath MJ, Boom WH, Goletti D, Gilman R, Lyadova IV, Scriba TJ, Kallas EG, Murali-Krishna K, Sette A, Lindestam Arlehamn CS. 2015. A side-by-side comparison of $\mathrm{T}$ cell reactivity to fifty-nine Mycobacterium 
tuberculosis antigens in diverse populations from five continents. Tuberculosis (Edinb) 95:713-721. http://dx.doi.org/10.1016/j.tube.2015.07 .001

50. Lindestam Arlehamn CS, Paul S, Mele F, Huang C, Greenbaum JA, Vita R, Sidney J, Peters B, Sallusto F, Sette A. 2015. Immunological consequences of intragenus conservation of Mycobacterium tuberculosis T-cell epitopes. Proc Natl Acad Sci USA 112:E147-E155. http://dx.doi .org/10.1073/pnas.1416537112

51. Day CL, Abrahams DA, Lerumo L, Janse van Rensburg E, Stone L, O'rie T, Pienaar B, de Kock M, Kaplan G, Mahomed H, Dheda K, Hanekom WA. 2011. Functional capacity of Mycobacterium tuberculosisspecific $\mathrm{T}$ cell responses in humans is associated with mycobacterial load. J Immunol 187:2222-2232. http://dx.doi.org/10.4049/jimmunol .1101122

52. Rozot V, Vigano S, Mazza-Stalder J, Idrizi E, Day CL, Perreau M, Lazor-Blanchet C, Petruccioli E, Hanekom W, Goletti D, Bart PA, Nicod L, Pantaleo G, Harari A. 2013. Mycobacterium tuberculosis-specific CD8 + T cells are functionally and phenotypically different between latent infection and active disease. Eur J Immunol 43:1568-1577. http://dx.doi .org/10.1002/eji.201243262

53. Rozot V, Patrizia A, Vigano S, Mazza-Stalder J, Idrizi E, Day CL, Perreau M, Lazor-Blanchet C, Ohmiti K, Goletti D, Bart P-A, Hanekom W, Scriba TJ, Nicod L, Pantaleo G, Harari A. 2015. Combined use of Mycobacterium tuberculosis-specific CD4 and CD8 T-cell responses is a powerful diagnostic tool of active tuberculosis. Clin Infect Dis 60:432437. http://dx.doi.org/10.1093/cid/ciu795

54. Seder RA, Darrah PA, Roederer M. 2008. T-cell quality in memory and protection: implications for vaccine design. Nat Rev Immunol 8:247258. http://dx.doi.org/10.1038/nri2274

55. Harari A, Rozot V, Bellutti Enders F, Perreau M, Stalder JM, Nicod LP, Cavassini M, Calandra T, Blanchet CL, Jaton K, Faouzi M, Day CL, Hanekom WA, Bart PA, Pantaleo G. 2011. Dominant TNF- $\alpha+$ Mycobacterium tuberculosis-specific CD4+ T cell responses discriminate between latent infection and active disease. Nat Med 17:372-376. http://dx .doi.org/10.1038/nm.2299

56. Riou C, Gray CM, Lugongolo M, Gwala T, Kiravu A, Deniso P, Stewart-Isherwood L, Omar SV, Grobusch MP, Coetzee G, Conradie F, Ismail N, Kaplan G, Fallows D. 2014. A subset of circulating blood mycobacteria-specific CD4 T cells can predict the time to Mycobacterium tuberculosis sputum culture conversion. PLoS One 9:e102178. http://dx .doi.org/10.1371/journal.pone.0102178

57. Sutherland JS, Adetifa IM, Hill PC, Adegbola RA, Ota MO. 2009. Pattern and diversity of cytokine production differentiates between Mycobacterium tuberculosis infection and disease. Eur J Immunol 39: 723-729. http://dx.doi.org/10.1002/eji.200838693

58. Caccamo N, Guggino G, Joosten SA, Gelsomino G, Di Carlo P, Titone L, Galati D, Bocchino M, Matarese A, Salerno A, Sanduzzi A, Franken WPJ, Ottenhoff THM, Dieli F. 2010. Multifunctional CD4(+) T cells correlate with active Mycobacterium tuberculosis infection. Eur J Immunol 40:2211-2220. http://dx.doi.org/10.1002/eji.201040455

59. Mueller H, Detjen AK, Schuck SD, Gutschmidt A, Wahn U, Magdorf K, Kaufmann SH, Jacobsen M. 2008. Mycobacterium tuberculosisspecific CD4+, IFNgamma+, and TNFalpha+ multifunctional memory $\mathrm{T}$ cells coexpress GM-CSF. Cytokine 43:143-148. http://dx.doi.org /10.1016/j.cyto.2008.05.002

60. Kagina BM, Abel B, Bowmaker M, Scriba TJ, Gelderbloem S, Smit E, Erasmus M, Nene N, Walzl G, Black G, Hussey GD, Hesseling AC, Hanekom WA. 2009. Delaying BCG vaccination from birth to 10 weeks of age may result in an enhanced memory CD4 T cell response. Vaccine 27:5488-5495. http://dx.doi.org/10.1016/j.vaccine.2009.06.103

61. Kagina BM, Abel B, Scriba TJ, Hughes EJ, Keyser A, Soares A, Gamieldien H, Sidibana M, Hatherill M, Gelderbloem S, Mahomed H, Hawkridge A, Hussey G, Kaplan G, Hanekom WA. 2010. Specific T cell frequency and cytokine expression profile do not correlate with protection against tuberculosis, following BCG vaccination of newborns. Am J Respir Crit Care Med 182:1073-1079. http://dx.doi.org/10.1164/rccm .201003-0334OC

62. Fletcher HA, Snowden MA, Landry B, Rida W, Satti I, Harris SA, Matsumiya M, Tanner R, O'Shea MK, Dheenadhayalan V, Bogardus L, Stockdale L, Marsay L, Chomka A, Harrington-Kandt R, ManjalyThomas Z-R, Naranbhai V, Stylianou E, Darboe F, Penn-Nicholson A, Nemes E, Hatheril M, Hussey G, Mahomed H, Tameris M, McClain JB, Evans TG, Hanekom WA, Scriba TJ, McShane H. 2016. T-cell activation is an immune correlate of risk in BCG vaccinated infants. Nat Commun 7:11290. http://dx.doi.org/10.1038/ncomms11290

63. Adekambi T, Ibegbu CC, Cagle S, Kalokhe AS, Wang YF, Hu Y, Day CL, Ray SM, Rengarajan J. 2015. Biomarkers on patient T cells diagnose active tuberculosis and monitor treatment response. J Clin Invest 125:1827-1838. http://dx.doi.org/10.1172/JCI77990

64. Esmail H, Barry CE III, Young DB, Wilkinson RJ. 2014. The ongoing challenge of latent tuberculosis. Philos Trans R Soc Lond B Biol Sci 369:20130437. http://dx.doi.org/10.1098/rstb.2013.0437

65. Perley CC, Frahm M, Click EM, Dobos KM, Ferrari G, Stout JE, Frothingham R. 2014. The human antibody response to the surface of Mycobacterium tuberculosis. PLoS One 9:e98938. http://dx.doi.org /10.1371/journal.pone.0098938

66. Yu X, Prados-Rosales R, Jenny-Avital ER, Sosa K, Casadevall A, Achkar JM. 2012. Comparative evaluation of profiles of antibodies to mycobacterial capsular polysaccharides in tuberculosis patients and controls stratified by HIV status. Clin Vaccine Immunol 19:198-208. http://dx.doi.org/10.1128/CVI.05550-11

67. Siev M, Wilson D, Kainth S, Kasprowicz VO, Feintuch CM, JennyAvital ER, Achkar JM. 2014. Antibodies against mycobacterial proteins as biomarkers for HIV-associated smear-negative tuberculosis. Clin Vaccine Immunol 21:791-798. http://dx.doi.org/10.1128/CVI.00805-13

68. Baumann R, Kaempfer S, Chegou NN, Oehlmann W, Spallek R, Loxton AG, van Helden PD, Black GF, Singh M, Walzl G. 2015. A subgroup of latently Mycobacterium tuberculosis infected individuals is characterized by consistently elevated IgA responses to several mycobacterial antigens. Mediators Inflamm 2015:364758. http://dx.doi.org /10.1155/2015/364758

69. Hoff ST, Abebe M, Ravn P, Range N, Malenganisho W, Rodriques DS, Kallas EG, Søborg C, Mark Doherty T, Andersen P, Weldingh K. 2007. Evaluation of Mycobacterium tuberculosis-specific antibody responses in populations with different levels of exposure from Tanzania, Ethiopia, Brazil, and Denmark. Clin Infect Dis 45:575-582. http://dx.doi .org/10.1086/520662

70. Chen J, Wang S, Zhang Y, Su X, Wu J, Shao L, Wang F, Zhang S, Weng X, Wang H, Zhang W. 2010. Rv1985c, a promising novel antigen for diagnosis of tuberculosis infection from BCG-vaccinated controls. BMC Infect Dis 10:273. http://dx.doi.org/10.1186/1471-2334-10-273

71. Hur YG, Kim A, Kang YA, Kim AS, Kim DY, Kim Y, Kim Y, Lee H, Cho SN. 2015. Evaluation of antigen-specific immunoglobulin g responses in pulmonary tuberculosis patients and contacts. J Clin Microbiol 53:904909. http://dx.doi.org/10.1128/JCM.03050-14

72. Niki M, Suzukawa M, Akashi S, Nagai H, Ohta K, Inoue M, Niki M, Kaneko Y, Morimoto K, Kurashima A, Kitada S, Matsumoto S, Suzuki K, Hoshino Y. 2015. Evaluation of humoral immunity to Mycobacterium tuberculosis-specific antigens for correlation with clinical status and effective vaccine development. J Immunol Res 2015:527395. http://dx.doi .org/10.1155/2015/527395

73. Bothamley GH, Beck JS, Potts RC, Grange JM, Kardjito T, Ivanyi J. 1992. Specificity of antibodies and tuberculin response after occupational exposure to tuberculosis. J Infect Dis 166:182-186. http://dx.doi.org /10.1093/infdis/166.1.182

74. Sousa AO, Salem JI, Lee FK, Verçosa MC, Cruaud P, Bloom BR, Lagrange PH, David HL. 1997. An epidemic of tuberculosis with a high rate of tuberculin anergy among a population previously unexposed to 
tuberculosis, the Yanomami Indians of the Brazilian Amazon. Proc Natl Acad Sci USA 94:13227-13232. http://dx.doi.org/10.1073/pnas.94.24 $\underline{.13227}$

75. Das S, Cheng SH, Lowrie DB, Walker KB, Mitchison DA, Vallishayee RS, Narayanan PR. 1992. The pattern of mycobacterial antigen recognition in sera from Mantoux-negative individuals is essentially unaffected by bacille Calmette-Guérin (BCG) vaccination in either south India or London. Clin Exp Immunol 89:402-406. http://dx.doi.org/10.1111 /j.1365-2249.1992.tb06970.x

76. Pilkington C, Costello AM, Rook GA, Stanford JL. 1993. Development of IgG responses to mycobacterial antigens. Arch Dis Child 69:644649. http://dx.doi.org/10.1136/adc.69.6.644

77. Stainsby KJ, Lowes JR, Allan RN, Ibbotson JP. 1993. Antibodies to Mycobacterium paratuberculosis and nine species of environmental mycobacteria in Crohn's disease and control subjects. Gut 34:371-374. http://dx.doi.org/10.1136/gut.34.3.371

78. Lagercrantz R, Enell H. 1953. Tuberculin-sensitivity and antibodies (agglutinins) after BCG-vaccination. Acta Paediatr 42:316-322. http://dx .doi.org/10.1111/j.1651-2227.1953.tb05598.x

79. Turneer M, Van Vooren JP, Nyabenda J, Legros F, Lecomte A, Thiriaux J, Serruys E, Yernault JC. 1988. The humoral immune response after BCG vaccination in humans: consequences for the serodiagnosis of tuberculosis. Eur Respir J 1:589-593.

80. Beyazova U, Rota S, Cevheroğlu C, Karsligil T. 1995. Humoral immune response in infants after BCG vaccination. Tuber Lung Dis 76:248253. http://dx.doi.org/10.1016/S0962-8479(05)80013-9

81. Hoft DF, Kemp EB, Marinaro M, Cruz O, Kiyono H, McGhee JR, Belisle JT, Milligan TW, Miller JP, Belshe RB. 1999. A double-blind, placebo-controlled study of Mycobacterium-specific human immune responses induced by intradermal bacille Calmette-Guérin vaccination. J Lab Clin Med 134:244-252. http://dx.doi.org/10.1016/S0022-2143(99) 90204-4

82. de Vallière S, Abate G, Blazevic A, Heuertz RM, Hoft DF. 2005. Enhancement of innate and cell-mediated immunity by antimycobacterial antibodies. Infect Immun 73:6711-6720. http://dx.doi.org/10.1128 /IAI.73.10.6711-6720.2005

83. Kumar SK, Singh P, Sinha S. 2015. Naturally produced opsonizing antibodies restrict the survival of Mycobacterium tuberculosis in human macrophages by augmenting phagosome maturation. Open Biol 5:150171. http://dx.doi.org/10.1098/rsob.150171

84. Grode L, Seiler P, Baumann S, Hess J, Brinkmann V, Nasser Eddine A, Mann P, Goosmann C, Bandermann S, Smith D, Bancroft GJ, Reyrat J-M, van Soolingen D, Raupach B, Kaufmann SHE. 2005. Increased vaccine efficacy against tuberculosis of recombinant Mycobacterium bovis bacille Calmette-Guérin mutants that secrete listeriolysin. J Clin Invest 115: 2472-2479. http://dx.doi.org/10.1172/JCI24617

85. Spertini F, Audran R, Chakour R, Karoui O, Steiner-Monard V, Thierry A-C, Mayor CE, Rettby N, Jaton K, Vallotton L, Lazor-Blanchet C, Doce J, Puentes E, Marinova D, Aguilo N, Martin C. 2015. Safety of human immunisation with a live-attenuated Mycobacterium tuberculosis vaccine: a randomised, double-blind, controlled phase I trial. Lancet Respir Med 3:953-962. http://dx.doi.org/10.1016/S2213-2600(15)00435-X

86. Knudsen NP, Olsen A, Buonsanti C, Follmann F, Zhang Y, Coler RN, Fox CB, Meinke A, D’Oro U, Casini D, Bonci A, Billeskov R, De Gregorio E, Rappuoli R, Harandi AM, Andersen P, Agger EM. 2016. Different human vaccine adjuvants promote distinct antigen-independent immunological signatures tailored to different pathogens. Sci Rep 6:19570. http://dx.doi.org/10.1038/srep19570

87. Ferebee SH. 1970. Controlled chemoprophylaxis trials in tuberculosis. A general review. Bibl Tuberc 26:28-106.

88. Wiker HG, Mustafa T, Bjune GA, Harboe M. 2010. Evidence for waning of latency in a cohort study of tuberculosis. BMC Infect Dis 10:37. http://dx.doi.org/10.1186/1471-2334-10-37
89. Opie EL, Aronson JD. 1927. Tubercle bacilli in latent tuberculous lesions and in lung tissue without tuberculous lesions. Arch Pathol Lab Med 4:1.

90. Keane J, Gershon S, Wise RP, Mirabile-Levens E, Kasznica J, Schwieterman WD, Siegel JN, Braun MM. 2001. Tuberculosis associated with infliximab, a tumor necrosis factor alpha-neutralizing agent. $\mathrm{N} \mathrm{EnglJ}$ Med 345:1098-1104. http://dx.doi.org/10.1056/NEJMoa011110

91. Singh JA, Wells GA, Christensen R, Tanjong Ghogomu E, Maxwell L, Macdonald JK, Filippini G, Skoetz N, Francis D, Lopes LC, Guyatt GH, Schmitt J, La Mantia L, Weberschock T, Roos JF, Siebert H, Hershan S, Lunn MP, Tugwell P, Buchbinder R. 2011. Adverse effects of biologics: a network meta-analysis and Cochrane overview. Cochrane Database Syst $\operatorname{Rev}(2)$ :CD008794.

92. Ernst JD. 2012. The immunological life cycle of tuberculosis. Nat Rev Immunol 12:581-591. http://dx.doi.org/10.1038/nri3259

93. Corbett EL, Watt CJ, Walker N, Maher D, Williams BG, Raviglione MC, Dye C. 2003. The growing burden of tuberculosis: global trends and interactions with the HIV epidemic. Arch Intern Med 163:1009-1021. http://dx.doi.org/10.1001/archinte.163.9.1009

94. Cegielski JP, McMurray DN. 2004. The relationship between malnutrition and tuberculosis: evidence from studies in humans and experimental animals. Int J Tuberc Lung Dis 8:286-298.

95. Nnoaham KE, Clarke A. 2008. Low serum vitamin D levels and tuberculosis: a systematic review and meta-analysis. Int J Epidemiol 37: 113-119. http://dx.doi.org/10.1093/ije/dym247

96. Oeltmann JE, Kammerer JS, Pevzner ES, Moonan PK. 2009. Tuberculosis and substance abuse in the United States, 1997-2006. Arch Intern Med 169:189-197. http://dx.doi.org/10.1001/archinternmed.2008.535

97. Ferrara G, Murray M, Winthrop K, Centis R, Sotgiu G, Migliori GB, Maeurer M, Zumla A. 2012. Risk factors associated with pulmonary tuberculosis: smoking, diabetes and anti-TNFa drugs. Curr Opin Pulm Med 18:233-240. http://dx.doi.org/10.1097/MCP.0b013e328351f9d6

98. Haug CJ, Aukrust P, Haug E, Mørkrid L, Müller F, Frøland SS. 1998. Severe deficiency of 1,25-dihydroxyvitamin D3 in human immunodeficiency virus infection: association with immunological hyperactivity and only minor changes in calcium homeostasis. I Clin Endocrinol Metab 83:3832-3838. http://dx.doi.org/10.1210/jcem.83.11.5270

99. Martineau AR, Wilkinson KA, Newton SM, Floto RA, Norman AW, Skolimowska K, Davidson RN, Sørensen OE, Kampmann B, Griffiths CJ, Wilkinson RJ. 2007. IFN-gamma- and TNF-independent vitamin D-inducible human suppression of mycobacteria: the role of cathelicidin LL-37. J Immunol 178:7190-7198. http://dx.doi.org/10.4049/jimmunol .178 .11 .7190

100. Kalsdorf B, Scriba TJ, Wood K, Day CL, Dheda K, Dawson R, Hanekom WA, Lange C, Wilkinson RJ. 2009. HIV-1 infection impairs the bronchoalveolar T-cell response to mycobacteria. Am J Respir Crit Care Med 180:1262-1270. http://dx.doi.org/10.1164/rccm.200907-1011OC

101. Campbell GR, Spector SA. 2011. Hormonally active vitamin D3 (1alpha,25-dihydroxycholecalciferol) triggers autophagy in human macrophages that inhibits HIV-1 infection. J Biol Chem 286:18890-18902. http://dx.doi.org/10.1074/jbc.M110.206110

102. Martineau AR, Nhamoyebonde S, Oni T, Rangaka MX, Marais S, Bangani N, Tsekela R, Bashe L, de Azevedo V, Caldwell J, Venton TR, Timms PM, Wilkinson KA, Wilkinson RJ. 2011. Reciprocal seasonal variation in vitamin $D$ status and tuberculosis notifications in Cape Town, South Africa. Proc Natl Acad Sci USA 108:19013-19017. http://dx.doi .org/10.1073/pnas.1111825108

103. Chaisson RE, Martinson NA. 2008. Tuberculosis in Africacombating an HIV-driven crisis. N Engl J Med 358:1089-1092. http://dx .doi.org/10.1056/NEJMp0800809

104. Coleman CM, Wu L. 2009. HIV interactions with monocytes and dendritic cells: viral latency and reservoirs. Retrovirology 6:51. http://dx .doi.org/10.1186/1742-4690-6-51 
105. Tsang J, Chain BM, Miller RF, Webb BL, Barclay W, Towers GJ, Katz DR, Noursadeghi M. 2009. HIV-1 infection of macrophages is dependent on evasion of innate immune cellular activation. AIDS 23:22552263. http://dx.doi.org/10.1097/QAD.0b013e328331a4ce

106. Diedrich CR, Flynn JL. 2011. HIV-1/mycobacterium tuberculosis coinfection immunology: how does HIV-1 exacerbate tuberculosis? Infect Immun 79:1407-1417. http://dx.doi.org/10.1128/IAI.01126-10

107. Sonnenberg P, Glynn JR, Fielding K, Murray J, Godfrey-Faussett P, Shearer S. 2005. How soon after infection with HIV does the risk of tuberculosis start to increase? A retrospective cohort study in South African gold miners. J Infect Dis 191:150-158. http://dx.doi.org/10.1086 1426827

108. Ranjbar S, Boshoff HI, Mulder A, Siddiqi N, Rubin EJ, Goldfeld AE. 2009. HIV-1 replication is differentially regulated by distinct clinical strains of Mycobacterium tuberculosis. PLoS One 4:e6116. http://dx.doi .org/10.1371/journal.pone.0006116

109. Pathak S, Wentzel-Larsen T, Asjö B. 2010. Effects of in vitro HIV-1 infection on mycobacterial growth in peripheral blood monocyte-derived macrophages. Infect Immun 78:4022-4032. http://dx.doi.org/10.1128 IIAI.00106-10

110. Ranjbar S, Jasenosky LD, Chow N, Goldfeld AE. 2012. Regulation of Mycobacterium tuberculosis-dependent HIV-1 transcription reveals a new role for NFAT5 in the toll-like receptor pathway. PLoS Pathog 8: e1002620. http://dx.doi.org/10.1371/journal.ppat.1002620

111. Toossi Z, Wu M, Hirsch CS, Mayanja-Kizza H, Baseke J, Aung H, Canaday DH, Fujinaga K. 2012. Activation of P-TEFb at sites of dual HIV/TB infection, and inhibition of MTB-induced HIV transcriptional activation by the inhibitor of CDK9, indirubin-3'-monoxime. AIDS Res Hum Retroviruses 28:182-187. http://dx.doi.org/10.1089/aid.2010.0211 112. Hoshino Y, Nakata K, Hoshino S, Honda Y, Tse DB, Shioda T, Rom WN, Weiden M. 2002. Maximal HIV-1 replication in alveolar macrophages during tuberculosis requires both lymphocyte contact and cytokines. J Exp Med 195:495-505. http://dx.doi.org/10.1084/jem.20011614 113. Toossi Z, Mayanja-Kizza H, Baseke J, Peters P, Wu M, Abraha A, Aung H, Okwera A, Hirsch C, Arts E. 2005. Inhibition of human immunodeficiency virus-1 (HIV-1) by beta-chemokine analogues in mononuclear cells from HIV-1-infected patients with active tuberculosis. Clin Exp Immunol 142:327-332. http://dx.doi.org/10.1111/j.1365-2249 $.2005 .02913 . \mathrm{x}$

114. Maddocks S, Scandurra GM, Nourse C, Bye C, Williams RB, Slobedman B, Cunningham AL, Britton WJ. 2009. Gene expression in HIV-1/Mycobacterium tuberculosis co-infected macrophages is dominated by M. tuberculosis. Tuberculosis (Edinb) 89:285-293. http://dx.doi .org/10.1016/j.tube.2009.05.003

115. Lagrange PH, Thangaraj SK, Dayal R, Deshpande A, Ganguly NK, Girardi E, Joshi B, Katoch K, Katoch VM, Kumar M, Lakshmi V, Leportier M, Longuet C, Malladi SV, Mukerjee D, Nair D, Raja A, Raman B, Rodrigues C, Sharma P, Singh A, Singh S, Sodha A, Kabeer BS, Vernet G, Goletti D. 2014. A toolbox for tuberculosis (TB) diagnosis: an Indian multi-centric study (2006-2008); evaluation of serological assays based on PGL-Tb1 and ESAT-6/CFP10 antigens for TB diagnosis. PLoS One 9: e96367. http://dx.doi.org/10.1371/journal.pone.0096367

116. Ashenafi S, Aderaye G, Zewdie M, Raqib R, Bekele A, Magalhaes I, Lema B, Habtamu M, Rekha RS, Aseffa G, Maeurer M, Aseffa A, Svensson M, Andersson J, Brighenti S. 2013. BCG-specific IgG-secreting peripheral plasmablasts as a potential biomarker of active tuberculosis in HIV negative and HIV positive patients. Thorax 68:269-276. http://dx .doi.org/10.1136/thoraxjnl-2012-201817

117. du Bruyn E, Wilkinson RJ. 2016. The immune interaction between HIV-1 infection and Mycobacterium tuberculosis. Microbiol Spectrum 4(5):TBTB2-0012-2016.

118. Dooley KE, Chaisson RE. 2009. Tuberculosis and diabetes mellitus: convergence of two epidemics. Lancet Infect Dis 9:737-746. http://dx.doi .org/10.1016/S1473-3099(09)70282-8
119. Stevenson CR, Forouhi NG, Roglic G, Williams BG, Lauer JA, Dye C, Unwin N. 2007. Diabetes and tuberculosis: the impact of the diabetes epidemic on tuberculosis incidence. BMC Public Health 7:234. http://dx .doi.org/10.1186/1471-2458-7-234

120. Restrepo BI. 2007. Convergence of the tuberculosis and diabetes epidemics: renewal of old acquaintances. Clin Infect Dis 45:436-438. http://dx.doi.org/10.1086/519939

121. Jeon CY, Murray MB. 2008. Diabetes mellitus increases the risk of active tuberculosis: a systematic review of 13 observational studies. PLoS Med 5:e152. http://dx.doi.org/10.1371/journal.pmed.0050152

122. Baker MA, Harries AD, Jeon CY, Hart JE, Kapur A, Lönnroth K, Ottmani SE, Goonesekera SD, Murray MB. 2011. The impact of diabetes on tuberculosis treatment outcomes: a systematic review. BMC Med 9:81. http://dx.doi.org/10.1186/1741-7015-9-81

123. Wang JY, Lee MC, Shu CC, Lee CH, Lee LN, Chao KM, Chang FY. 2015. Optimal duration of anti-TB treatment in patients with diabetes: nine or six months? Chest 147:520-528. http://dx.doi.org/10.1378/chest .14-0918

124. Gil-Santana L, Almeida-Junior JL, Oliveira CA, Hickson LS, Daltro C, Castro S, Kornfeld H, Netto EM, Andrade BB. 2016. Diabetes is associated with worse clinical presentation in tuberculosis patients from Brazil: a retrospective cohort study. PLoS One 11:e0146876. http://dx .doi.org/10.1371/journal.pone.0146876

125. Restrepo BI, Fisher-Hoch SP, Crespo JG, Whitney E, Perez A, Smith B, McCormick JB, Nuevo Santander Tuberculosis Trackers. 2007. Type 2 diabetes and tuberculosis in a dynamic bi-national border population. Epidemiol Infect 135:483-491. http://dx.doi.org/10.1017 /S0950268806006935

126. Corbett EL, Watt CJ, Walker N, Maher D, Williams BG, Raviglione MC, Dye C. 2003. The growing burden of tuberculosis: global trends and interactions with the HIV epidemic. Arch Intern Med 163:1009-1021. http://dx.doi.org/10.1001/archinte.163.9.1009

127. Restrepo BI, Schlesinger LS. 2013. Host-pathogen interactions in tuberculosis patients with type 2 diabetes mellitus. Tuberculosis (Edinb) 93(Suppl):S10-S14. http://dx.doi.org/10.1016/S1472-9792(13)70004-0

128. Shoelson SE, Lee J, Goldfine AB. 2006. Inflammation and insulin resistance. J Clin Invest 116:1793-1801. http://dx.doi.org/10.1172 /JCI29069

129. Restrepo BI, Fisher-Hoch SP, Pino PA, Salinas A, Rahbar MH, Mora F, Cortes-Penfield N, McCormick JB. 2008. Tuberculosis in poorly controlled type 2 diabetes: altered cytokine expression in peripheral white blood cells. Clin Infect Dis 47:634-641. http://dx.doi.org/10.1086 1590565

130. Jagannathan-Bogdan M, McDonnell ME, Shin H, Rehman Q, Hasturk H, Apovian CM, Nikolajczyk BS. 2011. Elevated proinflammatory cytokine production by a skewed $\mathrm{T}$ cell compartment requires monocytes and promotes inflammation in type 2 diabetes. J Immunol 186:1162-1172. http://dx.doi.org/10.4049/jimmunol.1002615

131. Kumar NP, Sridhar R, Banurekha VV, Jawahar MS, Fay MP, Nutman TB, Babu S. 2013. Type 2 diabetes mellitus coincident with pulmonary tuberculosis is associated with heightened systemic type 1 , type 17, and other proinflammatory cytokines. Ann Am Thorac Soc 10:441449. http://dx.doi.org/10.1513/AnnalsATS.201305-112OC

132. Jawad F, Shera AS, Memon R, Ansari G. 1995. Glucose intolerance in pulmonary tuberculosis. J Pak Med Assoc 45:237-238.

133. Tabarsi P, Baghaei P, Marjani M, Vollmer WM, Masjedi M-R, Harries AD. 2014. Changes in glycosylated haemoglobin and treatment outcomes in patients with tuberculosis in Iran: a cohort study. J Diabetes Metab Disord 13:123. http://dx.doi.org/10.1186/s40200-014-0123-0

134. Wilkinson RJ, Llewelyn M, Toossi Z, Patel P, Pasvol G, Lalvani A, Wright D, Latif M, Davidson RN. 2000. Influence of vitamin D deficiency and vitamin D receptor polymorphisms on tuberculosis among Gujarati Asians in west London: a case-control study. Lancet 355:618-621. http:// dx.doi.org/10.1016/S0140-6736(99)02301-6 
135. Talat N, Perry S, Parsonnet J, Dawood G, Hussain R. 2010. Vitamin $\mathrm{D}$ deficiency and tuberculosis progression. Emerg Infect Dis 16:853-855. http://dx.doi.org/10.3201/eid1605.091693

136. Martineau AR, Leandro AC, Anderson ST, Newton SM, Wilkinson KA, Nicol MP, Pienaar SM, Skolimowska KH, Rocha MA, Rolla VC, Levin M, Davidson RN, Bremner SA, Griffiths CJ, Eley BS, BoneciniAlmeida MG, Wilkinson RJ. 2010. Association between Gc genotype and susceptibility to TB is dependent on vitamin D status. Eur Respir J 35:1106-1112. http://dx.doi.org/10.1183/09031936.00087009

137. Coussens AK. 2011. Immunomodulatory actions of vitamin D metabolites and their potential relevance to human lung disease. Curr Rep Med Rev 7:444-453. http://dx.doi.org/10.2174/157339811798072577

138. Gombart AF, Borregaard N, Koeffler HP. 2005. Human cathelicidin antimicrobial peptide (CAMP) gene is a direct target of the vitamin D receptor and is strongly up-regulated in myeloid cells by 1,25dihydroxyvitamin D3. FASEB J 19:1067-1077. http://dx.doi.org/10.1096 Ifj.04-3284com

139. Sly LM, Lopez M, Nauseef WM, Reiner NE. 2001. 1alpha,25Dihydroxyvitamin D3-induced monocyte antimycobacterial activity is regulated by phosphatidylinositol 3-kinase and mediated by the NADPHdependent phagocyte oxidase. J Biol Chem 276:35482-35493. http://dx .doi.org/10.1074/jbc.M102876200

140. Rockett KA, Brookes R, Udalova I, Vidal V, Hill AV, Kwiatkowski D. 1998. 1,25-Dihydroxyvitamin D3 induces nitric oxide synthase and suppresses growth of Mycobacterium tuberculosis in a human macrophage-like cell line. Infect Immun 66:5314-5321.

141. Fratti RA, Backer JM, Gruenberg J, Corvera S, Deretic V. 2001. Role of phosphatidylinositol 3-kinase and Rab5 effectors in phagosomal biogenesis and mycobacterial phagosome maturation arrest. J Cell Biol 154:631-644. http://dx.doi.org/10.1083/jcb.200106049

142. Wang TT, Tavera-Mendoza LE, Laperriere D, Libby E, MacLeod NB, Nagai Y, Bourdeau V, Konstorum A, Lallemant B, Zhang R, Mader S, White JH. 2005. Large-scale in silico and microarray-based identification of direct 1,25-dihydroxyvitamin D3 target genes. Mol Endocrinol 19:2685-2695. http://dx.doi.org/10.1210/me.2005-0106

143. Liu PT, Stenger S, Tang DH, Modlin RL. 2007. Cutting edge: vitamin D-mediated human antimicrobial activity against Mycobacterium tuberculosis is dependent on the induction of cathelicidin. J Immunol 179:2060-2063. http://dx.doi.org/10.4049/jimmunol.179.4.2060

144. Coussens A, Timms PM, Boucher BJ, Venton TR, Ashcroft AT, Skolimowska KH, Newton SM, Wilkinson KA, Davidson RN, Griffiths CJ, Wilkinson RJ, Martineau AR. 2009. 1alpha,25-dihydroxyvitamin D3 inhibits matrix metalloproteinases induced by Mycobacterium tuberculosis infection. Immunology 127:539-548. http://dx.doi.org/10.1111 ji.1365-2567.2008.03024.x

145. Elkington P, Shiomi T, Breen R, Nuttall RK, Ugarte-Gil CA, Walker NF, Saraiva L, Pedersen B, Mauri F, Lipman M, Edwards DR, Robertson BD, D’Armiento J, Friedland JS. 2011. MMP-1 drives immunopathology in human tuberculosis and transgenic mice. J Clin Invest 121:1827-1833. http://dx.doi.org/10.1172/JCI45666

146. Boonstra A, Barrat FJ, Crain C, Heath VL, Savelkoul HF, O’Garra A. 2001. 1alpha,25-Dihydroxyvitamin d3 has a direct effect on naive CD4 (+) T cells to enhance the development of Th2 cells. J Immunol 167:49744980. http://dx.doi.org/10.4049/jimmunol.167.9.4974

147. Xystrakis E, Kusumakar S, Boswell S, Peek E, Urry Z, Richards DF, Adikibi T, Pridgeon C, Dallman M, Loke TK, Robinson DS, Barrat FJ, O'Garra A, Lavender P, Lee TH, Corrigan C, Hawrylowicz CM. 2006. Reversing the defective induction of IL-10-secreting regulatory T cells in glucocorticoid-resistant asthma patients. J Clin Invest 116:146-155. http://dx.doi.org/10.1172/JCI21759

148. Coussens AK, Wilkinson RJ, Hanifa Y, Nikolayevskyy V, Elkington PT, Islam K, Timms PM, Venton TR, Bothamley GH, Packe GE, Darmalingam M, Davidson RN, Milburn HJ, Baker LV, Barker RD, Mein CA, Bhaw-Rosun L, Nuamah R, Young DB, Drobniewski FA, Griffiths
CJ, Martineau AR. 2012. Vitamin D accelerates resolution of inflammatory responses during tuberculosis treatment. Proc Natl Acad Sci USA 109:15449-15454. http://dx.doi.org/10.1073/pnas.1200072109

149. Coussens AK, Martineau AR, Wilkinson RJ. 2014. Antiinflammatory and antimicrobial actions of vitamin D in combating TB/ HIV. Scientifica (Cairo) 2014:903680. http://dx.doi.org/10.1155/2014 1903680

150. Fabri M, Stenger S, Shin DM, Yuk JM, Liu PT, Realegeno S, Lee HM, Krutzik SR, Schenk M, Sieling PA, Teles R, Montoya D, Iyer SS, Bruns H, Lewinsohn DM, Hollis BW, Hewison M, Adams JS, Steinmeyer A, Zügel U, Cheng G, Jo EK, Bloom BR, Modlin RL. 2011. Vitamin D is required for IFN-gamma-mediated antimicrobial activity of human macrophages. Sci Transl Med 3:104ra102. http://dx.doi.org/10.1126 /scitranslmed.3003045

151. Schaible UE, Kaufmann SH. 2007. Malnutrition and infection: complex mechanisms and global impacts. PLoS Med 4:e115. http://dx .doi.org/10.1371/journal.pmed.0040115

152. Lönnroth K, Williams BG, Cegielski P, Dye C. 2010. A consistent log-linear relationship between tuberculosis incidence and body mass index. Int J Epidemiol 39:149-155. http://dx.doi.org/10.1093/ije/dyp308 153. Papathakis P, Piwoz E. 2008. Nutrition and Tuberculosis: A Review of the Literature and Considerations for TB Control Programs. USAID / Africa's Health in 2010 Project. http://digitalcommons.calpoly.edu/cgi /viewcontent.cgi? article $=1009 \&$ context $=$ fsn_fac

154. Vilchèze C, Hartman T, Weinrick B, Jacobs WRJ Jr. 2013. Mycobacterium tuberculosis is extraordinarily sensitive to killing by a vitamin C-induced Fenton reaction. Nat Commun 4:1881. http://dx.doi.org /10.1038/ncomms2898

155. Anand PK, Kaul D, Sharma M. 2008. Synergistic action of vitamin D and retinoic acid restricts invasion of macrophages by pathogenic mycobacteria. J Microbiol Immunol Infect 41:17-25.

156. Wheelwright M, Kim EW, Inkeles MS, De Leon A, Pellegrini M, Krutzik SR, Liu PT. 2014. All-trans retinoic acid-triggered antimicrobial activity against Mycobacterium tuberculosis is dependent on NPC2. J Immunol 192:2280-2290. http://dx.doi.org/10.4049/jimmunol.1301686 157. Karyadi E, West CE, Schultink W, Nelwan RH, Gross R, Amin Z, Dolmans WM, Schlebusch H, van der Meer JW. 2002. A double-blind, placebo-controlled study of vitamin A and zinc supplementation in persons with tuberculosis in Indonesia: effects on clinical response and nutritional status. Am J Clin Nutr 75:720-727.

158. Koch R. 1891. A further communication on a remedy for tuberculosis. BMJ 1:125-127. http://dx.doi.org/10.1136/bmj.1.1568.125

159. Roca FJ, Ramakrishnan L. 2013. TNF dually mediates resistance and susceptibility to mycobacteria via mitochondrial reactive oxygen species. Cell 153:521-534. http://dx.doi.org/10.1016/j.cell.2013.03.022

160. Brodin P, Jojic V, Gao T, Bhattacharya S, Angel CJ, Furman D, Shen-Orr S, Dekker CL, Swan GE, Butte AJ, Maecker HT, Davis MM. 2015. Variation in the human immune system is largely driven by nonheritable influences. Cell 160:37-47. http://dx.doi.org/10.1016/j.cell.2014 .12 .020

161. Maertzdorf J, Ota M, Repsilber D, Mollenkopf HJ, Weiner J, Hill PC, Kaufmann SH. 2011. Functional correlations of pathogenesis-driven gene expression signatures in tuberculosis. PLoS One 6:e26938. http://dx .doi.org/10.1371/journal.pone.0026938

162. Maertzdorf J, Repsilber D, Parida SK, Stanley K, Roberts T, Black G, Walzl G, Kaufmann SH. 2011. Human gene expression profiles of susceptibility and resistance in tuberculosis. Genes Immun 12:15-22. http:// dx.doi.org/10.1038/gene.2010.51

163. Ottenhoff TH, Dass RH, Yang N, Zhang MM, Wong HE, Sahiratmadja E, Khor CC, Alisjahbana B, van Crevel R, Marzuki S, Seielstad M, van de Vosse E, Hibberd ML. 2012. Genome-wide expression profiling identifies type 1 interferon response pathways in active tuberculosis. PLoS One 7:e45839. http://dx.doi.org/10.1371/journal.pone .0045839 
164. Cliff JM, Lee JS, Constantinou N, Cho JE, Clark TG, Ronacher K, King EC, Lukey PT, Duncan K, Van Helden PD, Walzl G, Dockrell HM. 2013. Distinct phases of blood gene expression pattern through tuberculosis treatment reflect modulation of the humoral immune response. J Infect Dis 207:18-29. http://dx.doi.org/10.1093/infdis/jis499

165. Bloom CI, Graham CM, Berry MP, Rozakeas F, Redford PS, Wang Y, Xu Z, Wilkinson KA, Wilkinson RJ, Kendrick Y, Devouassoux G, Ferry T, Miyara M, Bouvry D, Valeyre D, Gorochov G, Blankenship $D$, Saadatian M, Vanhems P, Beynon H, Vancheeswaran R, Wickremasinghe M, Chaussabel D, Banchereau J, Pascual V, Ho LP, Lipman M, O’Garra A. 2013. Transcriptional blood signatures distinguish pulmonary tuberculosis, pulmonary sarcoidosis, pneumonias and lung cancers. PLoS One 8:e70630. http://dx.doi.org/10.1371/journal .pone.0070630

166. de Paus RA, van Wengen A, Schmidt I, Visser M, Verdegaal EM, van Dissel JT, van de Vosse E. 2013. Inhibition of the type I immune responses of human monocytes by IFN- $\alpha$ and IFN- $\beta$. Cytokine 61:645-655. http:// dx.doi.org/10.1016/j.cyto.2012.12.005

167. Mayer-Barber KD, Andrade BB, Oland SD, Amaral EP, Barber DL, Gonzales J, Derrick SC, Shi R, Kumar NP, Wei W, Yuan X, Zhang G, Cai Y, Babu S, Catalfamo M, Salazar AM, Via LE, Barry CE III, Sher A. 2014. Host-directed therapy of tuberculosis based on interleukin-1 and type I interferon crosstalk. Nature 511:99-103. http://dx.doi.org /10.1038/nature13489

168. Rogers PM. 1928. A study of the blood monocytes in children with tuberculosis. N Engl J Med 198:740-749. http://dx.doi.org/10.1056 INEJM192805241981410

169. Doan CA, Sabin FR. 1930. Studies on tuberculosis. IV. The relation of the tubercle and the monocyte:lymphocyte ratio to resistance and susceptibility in tuberculosis. J Exp Med 52(Suppl 3):113-152. http://dx.doi .org/10.1084/jem.52.90063.113

170. Murray PJ, Allen JE, Biswas SK, Fisher EA, Gilroy DW, Goerdt S, Gordon S, Hamilton JA, Ivashkiv LB, Lawrence T, Locati M, Mantovani A, Martinez FO, Mege J-L, Mosser DM, Natoli G, Saeij JP, Schultze JL, Shirey KA, Sica A, Suttles J, Udalova I, van Ginderachter JA, Vogel SN, Wynn TA. 2014. Macrophage activation and polarization: nomenclature and experimental guidelines. Immunity 41:14-20. http://dx.doi.org /10.1016/j.immuni.2014.06.008

171. Lastrucci C, Bénard A, Balboa L, Pingris K, Souriant S, Poincloux R, Al Saati T, Rasolofo V, González-Montaner P, Inwentarz S, Moraña EJ, Kondova I, Verreck FA, Sasiain MC, Neyrolles O, Maridonneau-Parini I, Lugo-Villarino G, Cougoule C. 2015. Tuberculosis is associated with expansion of a motile, permissive and immunomodulatory CD16(+) monocyte population via the IL-10/STAT3 axis. Cell Res 25:1333-1351. http://dx.doi.org/10.1038/cr.2015.123

172. Dorhoi A, Kaufmann SH. 2014. Perspectives on host adaptation in response to Mycobacterium tuberculosis: modulation of inflammation. Semin Immunol 26:533-542. http://dx.doi.org/10.1016/j.smim.2014 $\underline{.10 .002}$

173. Naranbhai V, Fletcher HA, Tanner R, O'Shea MK, McShane H, Fairfax BP, Knight JC, Hill AV. 2015. Distinct transcriptional and antimycobacterial profiles of peripheral blood monocytes dependent on the ratio of monocytes: lymphocytes. EBioMedicine 2:1619-1626. http://dx .doi.org/10.1016/j.ebiom.2015.09.027

174. Naranbhai V, Hill AV, Abdool Karim SS, Naidoo K, Abdool Karim Q, Warimwe GM, McShane H, Fletcher H. 2014. Ratio of monocytes to lymphocytes in peripheral blood identifies adults at risk of incident tuberculosis among HIV-infected adults initiating antiretroviral therapy. J Infect Dis 209:500-509. http://dx.doi.org/10.1093/infdis /jit494

175. Naranbhai V, Moodley D, Chipato T, Stranix-Chibanda L, Nakabaiito C, Kamateeka M, Musoke P, Manji K, George K, Emel LM, Richardson P, Andrew P, Fowler M, Fletcher H, McShane H, Coovadia HM, Hill AV, HPTN 046 Protocol Team. 2014. The association between the ratio of monocytes: lymphocytes and risk of tuberculosis among
HIV-infected postpartum women. J Acquir Immune Defic Syndr 67:573575. http://dx.doi.org/10.1097/QAI.0000000000000353

176. Naranbhai V, Kim S, Fletcher H, Cotton MF, Violari A, Mitchell C, Nachman S, McSherry G, McShane H, Hill AV, Madhi SA. 2014. The association between the ratio of monocytes:lymphocytes at age 3 months and risk of tuberculosis (TB) in the first two years of life. BMC Med 12:120. http://dx.doi.org/10.1186/s12916-014-0120-7

177. Rakotosamimanana N, Richard V, Raharimanga V, Gicquel B, Doherty TM, Zumla A, Rasolofo Razanamparany V. 2015. Biomarkers for risk of developing active tuberculosis in contacts of TB patients: a prospective cohort study. Eur Respir J 46:1095-1103. http://dx.doi.org /10.1183/13993003.00263-2015

178. Schaale K, Brandenburg J, Kispert A, Leitges M, Ehlers S, Reiling N. 2013. Wnt6 is expressed in granulomatous lesions of Mycobacterium tuberculosis-infected mice and is involved in macrophage differentiation and proliferation. J Immunol 191:5182-5195. http://dx.doi.org/10.4049 /jimmunol.1201819

179. Labonte AC, Tosello-Trampont AC, Hahn YS. 2014. The role of macrophage polarization in infectious and inflammatory diseases. $\mathrm{Mol}$ Cells 37:275-285. http://dx.doi.org/10.14348/molcells.2014.2374

180. Parks WC, Wilson CL, López-Boado YS. 2004. Matrix metalloproteinases as modulators of inflammation and innate immunity. Nat Rev Immunol 4:617-629. http://dx.doi.org/10.1038/nri1418

181. Welgus HG, Campbell EJ, Cury JD, Eisen AZ, Senior RM, Wilhelm SM, Goldberg GI. 1990. Neutral metalloproteinases produced by human mononuclear phagocytes. Enzyme profile, regulation, and expression during cellular development. J Clin Invest 86:1496-1502. http://dx.doi .org/10.1172/JCI114867

182. Elkington PT, Nuttall RK, Boyle JJ, O'Kane CM, Horncastle DE, Edwards DR, Friedland JS. 2005. Mycobacterium tuberculosis, but not vaccine BCG, specifically upregulates matrix metalloproteinase- 1 . Am J Respir Crit Care Med 172:1596-1604. http://dx.doi.org/10.1164/rccm .200505-7530C

183. Chang JC, Wysocki A, Tchou-Wong KM, Moskowitz N, Zhang Y, Rom WN. 1996. Effect of Mycobacterium tuberculosis and its components on macrophages and the release of matrix metalloproteinases. Thorax 51:306-311. http://dx.doi.org/10.1136/thx.51.3.306

184. Busiek DF, Baragi V, Nehring LC, Parks WC, Welgus HG. 1995. Matrilysin expression by human mononuclear phagocytes and its regulation by cytokines and hormones. J Immunol 154:6484-6491.

185. Zhang Y, McCluskey K, Fujii K, Wahl LM. 1998. Differential regulation of monocyte matrix metalloproteinase and TIMP-1 production by TNF-alpha, granulocyte-macrophage CSF, and IL-1 beta through prostaglandin-dependent and -independent mechanisms. J Immunol 161: 3071-3076.

186. Lacraz S, Nicod L, Galve-de Rochemonteix B, Baumberger C, Dayer JM, Welgus HG. 1992. Suppression of metalloproteinase biosynthesis in human alveolar macrophages by interleukin-4. J Clin Invest 90:382-388. http://dx.doi.org/10.1172/JCI115872

187. Lacraz S, Nicod LP, Chicheportiche R, Welgus HG, Dayer JM. 1995. IL-10 inhibits metalloproteinase and stimulates TIMP-1 production in human mononuclear phagocytes. J Clin Invest 96:2304-2310. http://dx .doi.org/10.1172/JCI118286

188. Tameris MD, Hatherill M, Landry BS, Scriba TJ, Snowden MA, Lockhart S, Shea JE, McClain JB, Hussey GD, Hanekom WA, Mahomed H, McShane H, MVA85A 020 Trial Study Team. 2013. Safety and efficacy of MVA85A, a new tuberculosis vaccine, in infants previously vaccinated with BCG: a randomised, placebo-controlled phase $2 \mathrm{~b}$ trial. Lancet 381:1021-1028. http://dx.doi.org/10.1016/S0140-6736(13)60177-4

189. Andrews JR, Hatherill M, Mahomed H, Hanekom WA, Campo M, Hawn TR, Wood R, Scriba TJ. 2015. The dynamics of QuantiFERON-TB gold in-tube conversion and reversion in a cohort of South African adolescents. Am J Respir Crit Care Med 191:584-591. http://dx.doi.org /10.1164/rccm.201409-1704OC 
190. Vynnycky E, Fine PE. 1999. Interpreting the decline in tuberculosis: the role of secular trends in effective contact. Int J Epidemiol 28:327-334. http://dx.doi.org/10.1093/ije/28.2.327

191. Vynnycky E, Fine PE. 2000. Lifetime risks, incubation period, and serial interval of tuberculosis. Am J Epidemiol 152:247-263. http://dx .doi.org/10.1093/aje/152.3.247

192. Fine PE, Bruce J, Ponnighaus JM, Nkhosa P, Harawa A, Vynnycky E. 1999. Tuberculin sensitivity: conversions and reversions in a rural African population. Int J Tuberc Lung Dis 3:962-975.

193. Dahlstrom AW. 1940. The instability of the tuberculin reaction. Am Rev Tuberc 42:471.

194. Gordin FM, Perez-Stable EJ, Reid M, Schecter G, Cosgriff L, Flaherty D, Hopewell PC. 1991. Stability of positive tuberculin tests: are boosted reactions valid? Am Rev Respir Dis 144:560-563. http://dx.doi.org /10.1164/ajrccm/144.3_Pt_1.560

195. Kunnath-Velayudhan S, Davidow AL, Wang HY, Molina DM, Huynh VT, Salamon H, Pine R, Michel G, Perkins MD, Xiaowu L, Felgner PL, Flynn JL, Catanzaro A, Gennaro ML. 2012. Proteome-scale antibody responses and outcome of Mycobacterium tuberculosis infection in nonhuman primates and in tuberculosis patients. J Infect Dis 206:697705. http://dx.doi.org/10.1093/infdis/jis421

196. Steingart KR, Flores LL, Dendukuri N, Schiller I, Laal S, Ramsay A, Hopewell PC, Pai M. 2011. Commercial serological tests for the diagnosis of active pulmonary and extrapulmonary tuberculosis: an updated systematic review and meta-analysis. PLoS Med 8:e1001062. http://dx.doi .org/10.1371/journal.pmed.1001062

197. Maes RF. 1991. Evaluation of the avidity of IgG anti-mycobacterial antibodies in tuberculous patients serum by an A-60 immunoassay. Eur J Epidemiol 7:188-190. http://dx.doi.org/10.1007/BF00237365

198. Arias-Bouda LM, Kuijper S, Van der Werf A, Nguyen LN, Jansen HM, Kolk AH. 2003. Changes in avidity and level of immunoglobulin G antibodies to Mycobacterium tuberculosis in sera of patients undergoing treatment for pulmonary tuberculosis. Clin Diagn Lab Immunol 10:702709.

199. Carroll MV, Lack N, Sim E, Krarup A, Sim RB. 2009. Multiple routes of complement activation by Mycobacterium bovis BCG. Mol Immunol 46:3367-3378. http://dx.doi.org/10.1016/j.molimm.2009.07 .015

200. Carroll MV, Lack N, Sim E, Krarup A, Sim RB. 2009. Multiple routes of complement activation by Mycobacterium bovis BCG. Mol Immunol 46:3367-3378. http://dx.doi.org/10.1016/j.molimm.2009.07 .015

201. Jacobsen M, Repsilber D, Gutschmidt A, Neher A, Feldmann K, Mollenkopf HJ, Ziegler A, Kaufmann SH. 2007. Candidate biomarkers for discrimination between infection and disease caused by Mycobacterium tuberculosis. J Mol Med Berl 85:613-621. http://dx.doi.org /10.1007/s00109-007-0157-6

202. Laux da Costa L, Delcroix M, Dalla Costa ER, Prestes IV, Milano M, Francis SS, Unis G, Silva DR, Riley LW, Rossetti ML. 2015. A real-time PCR signature to discriminate between tuberculosis and other pulmonary diseases. Tuberculosis (Edinb) 95:421-425. http://dx.doi.org/10.1016/i tube.2015.04.008

203. Pai M. 2010. Spectrum of latent tuberculosis - existing tests cannot resolve the underlying phenotypes. Nat Rev Microbiol 8:242. doi:10.1038 Inrmicro2236-c1

204. Young DB, Gideon HP, Wilkinson RJ. 2009. Eliminating latent tuberculosis. Trends Microbiol 17:183-188. http://dx.doi.org/10.1016/i tim.2009.02.005

205. Esmail H, Barry CE III, Wilkinson RJ. 2012. Understanding latent tuberculosis: the key to improved diagnostic and novel treatment strategies. Drug Discov Today 17:514-521. http://dx.doi.org/10.1016/j.drudis .2011 .12 .013

206. Kaforou M, Wright VJ, Oni T, French N, Anderson ST, Bangani N, Banwell CM, Brent AJ, Crampin AC, Dockrell HM, Eley B, Heyderman
RS, Hibberd ML, Kern F, Langford PR, Ling L, Mendelson M, Ottenhoff TH, Zgambo F, Wilkinson RJ, Coin LJ, Levin M. 2013. Detection of tuberculosis in HIV-infected and -uninfected African adults using whole blood RNA expression signatures: a case-control study. PLoS Med 10:e1001538. http://dx.doi.org/10.1371/journal.pmed .1001538

207. Sloot R, Schim van der Loeff MF, van Zwet EW, Haks MC, Keizer ST, Scholing M, Ottenhoff THM, Borgdorff MW, Joosten SA. 2014. Biomarkers can identify pulmonary tuberculosis in HIV-infected drug users months prior to clinical diagnosis. EBioMedicine 2:172-179. http:// dx.doi.org/10.1016/j.ebiom.2014.12.001

208. Deffur A, Wilkinson RJ, Coussens AK. 2015. Tricks to translating TB transcriptomics. Ann Transl Med 3(Suppl 1):S43.

209. Zak DE, Penn-Nicholson A, Scriba TJ, Thompson E, Suliman S, Amon LM, Mahomed H, Erasmus M, Whatney W, Hussey GD, Abrahams D, Kafaar F, Hawkridge T, Verver S, Hughes EJ, Ota M, Sutherland J, Howe R, Dockrell HM, Boom WH, Thiel B, Ottenhoff THM, Mayanja-Kizza H, Crampin AC, Downing K, Hatherill M, Valvo J, Shankar S, Parida SK, Kaufmann SHE, Walzl G, Aderem A, Hanekom WA, ACS and GC6-74 cohort study groups. 2016. A blood RNA signature for tuberculosis disease risk: a prospective cohort study. Lancet 387:2312-2322. http://dx.doi.org/10.1016/S0140-6736(15)01316-1

210. Esmail H, Lai RP, Lesosky M, Wilkinson KA, Graham CM, Coussens AK, Oni T, Warwick JM, Said-Hartley Q, Koegelenberg CF, Walzl G, Flynn JL, Young DB, Barry CE III, O'Garra A, Wilkinson RJ. 2016. Characterization of progressive HIV-associated tuberculosis using 2-deoxy-2-[(18)F]fluoro-D-glucose positron emission and computed tomography. Nat Med 22:1090-1093. http://dx.doi.org/10.1038 Inm.4161

211. De Groote MA, Nahid P, Jarlsberg L, Johnson JL, Weiner M, Muzanyi G, Janjic N, Sterling DG, Ochsner UA. 2013. Elucidating novel serum biomarkers associated with pulmonary tuberculosis treatment. PLoS One 8:e61002. http://dx.doi.org/10.1371/journal.pone.0061002

212. Wergeland I, Pullar N, Assmus J, Ueland T, Tonby K, Feruglio S, Kvale D, Damås JK, Aukrust P, Mollnes TE, Dyrhol-Riise AM. 2015. IP-10 differentiates between active and latent tuberculosis irrespective of HIV status and declines during therapy. J Infect 70:381-391. http://dx .doi.org/10.1016/j.jinf.2014.12.019

213. Agranoff D, Fernandez-Reyes D, Papadopoulos MC, Rojas SA, Herbster M, Loosemore A, Tarelli E, Sheldon J, Schwenk A, Pollok R, Rayner CF, Krishna S. 2006. Identification of diagnostic markers for tuberculosis by proteomic fingerprinting of serum. Lancet 368:1012-1021. http://dx.doi.org/10.1016/S0140-6736(06)69342-2

214. Brahmbhatt S, Black GF, Carroll NM, Beyers N, Salker F, Kidd M, Lukey PT, Duncan K, van Helden P, Walzl G. 2006. Immune markers measured before treatment predict outcome of intensive phase tuberculosis therapy. Clin Exp Immunol 146:243-252. http://dx.doi.org/10.1111 j.1365-2249.2006.03211.x

215. Djoba Siawaya JF, Bapela NB, Ronacher K, Beyers N, van Helden P, Walzl G. 2008. Differential expression of interleukin-4 (IL-4) and IL-4 delta 2 mRNA, but not transforming growth factor beta (TGF-beta), TGF-beta RII, Foxp3, gamma interferon, T-bet, or GATA-3 mRNA, in patients with fast and slow responses to antituberculosis treatment. Clin Vaccine Immunol 15:1165-1170. http://dx.doi.org/10.1128/CVI.00084 $\underline{-08}$

216. Djoba Siawaya JF, Bapela NB, Ronacher K, Veenstra H, Kidd M, Gie R, Beyers N, van Helden P, Walzl G. 2008. Immune parameters as markers of tuberculosis extent of disease and early prediction of antituberculosis chemotherapy response. J Infect 56:340-347. http://dx.doi .org/10.1016/j.jinf.2008.02.007

217. Baumann R, Kaempfer S, Chegou NN, Nene NF, Veenstra H, Spallek R, Bolliger CT, Lukey PT, van Helden PD, Singh M, Walzl G. 2013. Serodiagnostic markers for the prediction of the outcome of intensive phase tuberculosis therapy. Tuberculosis (Edinb) 93:239-245. http://dx.doi.org/10.1016/j.tube.2012.09.003 
218. Feng $X$, Yang $X$, Xiu B, Qie S, Dai Z, Chen K, Zhao P, Zhang L, Nicholson RA, Wang G, Song X, Zhang H. 2014. IgG, IgM and IgA antibodies against the novel polyprotein in active tuberculosis. BMC Infect Dis 14:336. http://dx.doi.org/10.1186/1471-2334 $\underline{-14-336}$

219. Cliff JM, Kaufmann SH, McShane H, van Helden P, O'Garra A. 2015. The human immune response to tuberculosis and its treatment: a view from the blood. Immunol Rev 264:88-102. http://dx.doi.org /10.1111/imr.12269
220. Cornil V, Ranvier L. 1880. A Manual of Pathological Histology. Part III. Henry G. Lea, Philadelphia, PA.

221. Hamilton DJ. 1883. On the Pathology of Bronchitis, Catarrhal Pneumonia, Tubercle, and Allied Lesions of the Human Lung. Macmillan and Co., London, United Kingdom.

222. Baumann R, Kaempfer S, Chegou NN, Oehlmann W, Loxton AG, Kaufmann SH, van Helden PD, Black GF, Singh M, Walzl G. 2014. Serologic diagnosis of tuberculosis by combining Ig classes against selected mycobacterial targets. J Infect 69:581-589. 